\title{
1 Exposure to stressors and antimicrobials induces cell-autonomous 2 ultrastructural heterogeneity of an intracellular bacterial pathogen
}

4 Marc Schulte, Michael Hensel, and Katarzyna Miskiewicz

5 Abt. Mikrobiologie, Universität Osnabrïck, Osnabrück, Germany, CellNanOs - Center of

6 Cellular Nanoanalytics Osnabrück

7

8 Running title: Intracellular Salmonella ultrastructural heterogeneity

9 Keywords: intracellular pathogen, bacterial heterogeneity, stress response, bacterial

10 cytoplasm, CLEM

11

12 Address for correspondence:

13 Michael Hensel

14 Abteilung Mikrobiologie

15 Fachbereich Biologie/Chemie, Universität Osnabrück

16 Barbarastr. 11

1749076 Osnabrück, Germany

18 Tel: ++ $49(0) 5419693940$

19 Fax: ++ $49(0) 5419693942$

20 E-mail: Michael.Hensel@uni-osnabrueck.de 


\section{Abstract}

Despite being clonal, bacterial pathogens show a remarkable physiological heterogeneity during infection of host and within host cells. This diversity is reflected by distinct ultrastructural morphotypes in transmission electron microscopy (TEM). Gram-negative bacteria visualized at high resolution by TEM show a rather simple composition of cytoplasm with a centrally located nucleoid and large number of ribosomes. The cytoplasm is separated from the external environment by inner and outer membranes. In this study, we show that individual cells of Salmonella enterica serovar Typhimurium (STM) are ultrastructural divergent in standard culture conditions, as well as during their intracellular lifestyle in mammalian host cells. STM can basically be discriminated into two morphotypes based on the criterion of cytoplasmic density. We identified environmental conditions which affect cytoplasmic densities. Using chemical treatments and defined mutant strains, we were able to link the occurrence of an electron-dense type to oxidative stress and other noxes. Furthermore, ultrastructural analyses of STM during infection and fluorescence reporter analyses for cell viability were combined in a correlative light and electron microscopy approach. We provide evidence that two newly characterized ultrastructural types with lucent or dense cytoplasm represent viable cells. Moreover, the presence of electron-dense types is stress related and can be experimentally induced only when amino acids are available in the environment. This study sheds more light on diversities between individual bacteria in populations and possible physiological meanings like a stress response to explain the diversities discussed.

\section{Importance}

Bacterial pathogens show a remarkable resilience to adverse conditions during infection. Although being genetically identical, a clonal population may contain dead, dormant, slowly 
bioRxiv preprint doi: https://doi org/10.1101/2020.09.14.297432; this version posted September 17, 2020. The copyright holder for this preprint (which was not certified by peer review) is the author/funder, who has granted bioRxiv a license to display the preprint in perpetuity. It is made available under aCC-BY-ND 4.0 International license.

Intracellular Salmonella ultrastructural heterogeneity

as well as rapidly proliferating cells. The physiological state of individual cells in a

population may be analyzed by fluorescent probes or reporters. In contrast, reliable markers to interrogate single cells regarding viability, response to environmental cues, and exposure to

49 antimicrobial compounds are sparse for ultrastructural approaches. For intracellular

50 Salmonella enterica we observed distinct ultrastructural morphotypes. Using defined

51 experimental conditions, these morphotypes were linked to reactions of bacteria to stressors

52 or antimicrobials. The parameters defined here provide criteria for the interpretation of 53 bacterial heterogeneity on the ultrastructural level. 
bioRxiv preprint doi: https://doi.org/10.1101/2020.09.14.297432; this version posted September 17, 2020. The copyright holder for this preprint (which was not certified by peer review) is the author/funder, who has granted bioRxiv a license to display the preprint in perpetuity. It is made available under aCC-BY-ND 4.0 International license.

12.09.2020

Intracellular Salmonella ultrastructural heterogeneity

\section{Introduction}

Recent research on pathogenic bacteria revealed that cells react individually when exposed to adverse conditions due to differences in their physiological status (1-7). Classification of diversities and understanding of their biological function are crucial for designing new antimicrobials, which would overcome bacterial resistance without the risk of imposing selective pressure towards bacterial survival. Despite great progress in understanding the role of individual virulence factors for bacterial pathogenesis, the resilient bacterial survival in detrimental environmental conditions is still enigmatic (8-10). In the context of stress response to environmental cues, the formation of a dormant state with metabolic shifts, and change in cytoplasmic dynamics was postulated $(11,12)$. In general, bacterial cells appear structurally more complex than previously considered. For instance, the bacterial cytoplasm displays, in addition to high molecular crowding, unusual motility dynamics for differentlysized particles, properties of glass-phase, or transitions to solid-states $(13,14)$.

Transmission EM (TEM) is very potent to visualize the composition of bacterial envelopes, protein complexes, and has shed light on protein shell structures, revolutionizing the view on bacterial organelles $(15,16)$. Conventional TEM is broadly used as standard method to evaluate effects of bactericidal compounds $(6,17-21)$. In contrast, TEM was rarely applied to describe diversities of pathogenic bacteria at the single-cell level.

Bacterial cells visualized by EM demonstrate high ultrastructural variability, but the causes of this diversity are unknown (22-34). Distinct reactions to environmental stress can be a reason for such heterogeneity, as shown for aquatic microorganisms (35). However, direct links between physiological state, stress factors, and the bacterial ultrastructure have not been demonstrated. Identification of such links could delineate indicators of changes or circumstances critical for bacterial survival, to predict formation of persisters, to estimate sensitivities of populations, or to develop preventive strategies against bacterial infections. 
bioRxiv preprint doi: https://doi.org/10.1101/2020.09.14.297432; this version posted September 17, 2020. The copyright holder for this preprint (which was not certified by peer review) is the author/funder, who has granted bioRxiv a license to display the preprint in perpetuity. It is made available under aCC-BY-ND 4.0 International license.

12.09.2020

Intracellular Salmonella ultrastructural heterogeneity

80

81

Hence, the investigation of different ultrastructural types and their frequencies may allow to predict prevailing environmental conditions, especially in the background of analyses of intracellular pathogens, or analyses of bacterial populations in vivo or free-living isolates.

The capability of Salmonella enterica serovar Typhimurium (STM) to survive harsh conditions in environments within and outside of mammalian hosts makes it a good model organism to reveal the basis of bacterial heterogeneity. STM is a foodborne pathogen, capable to pass the low pH barrier of the stomach. STM is exposed to host defense mechanisms and competing microbes in the host gastrointestinal tract. STM can invade epithelial cells, survive and proliferate in host cells, and can abuses phagocytes for spreading and replication within phagosomes. Within host cells, STM is enclosed by a specific vacuole (Salmonella-containing vacuole, SCV) and drives the formation of tubular membrane network (Salmonella-induced filaments, SIF), supporting its intracellular survival and progression (36-38). Moreover, STM is capable to survive and replicate within the host cell cytoplasm after escaping the SCV (39). Intracellular survival requires fast stress response and cellular reprogramming for protection and repair when facing strong bactericidal host defenses such as reactive oxygen species (ROS) (40-43).

In this study, we shed light on the consequences of environmental changes and exposure to stress factors for the bacterial ultrastructure. We demonstrate that heterogeneity, at the singlecell level, and ultrastructural homogeneity depend on the environment and can be experimentally induced. The approach presented here enables to link ultrastructural diversity with the physiological status of individual bacteria and environmental cues. For that, we combined classical microbiological assays with qualitative and quantitative TEM to study effects of induced oxidative stress and bactericidal conditions in STM wild type (WT) and the $\operatorname{sod} A B$ strain hypersensitive to ROS. Furthermore, we developed a strategy for fast correlative light and electron microscopy (CLEM) using high-voltage TEM of thick serial sections, and a fluorescent reporter for measuring bacterial metabolic activity. These results validate that 
bioRxiv preprint doi: https://doi.org/10.1101/2020.09.14.297432; this version posted September 17, 2020. The copyright holder for this preprint (which was not certified by peer review) is the author/funder, who has granted bioRxiv a license to display the preprint in perpetuity. It is made available under aCC-BY-ND 4.0 International license.

12.09.2020

Intracellular Salmonella ultrastructural heterogeneity

106 different ultrastructural types are viable bacteria. The combination of ultrastructural studies at

107 the single-cell level with fluorescent reporters is the next step towards an understanding of 108 bacteria as individual organisms and their lifestyles.

109 
bioRxiv preprint doi: https://doi.org/10.1101/2020.09.14.297432; this version posted September 17, 2020. The copyright holder for this preprint (which was not certified by peer review) is the author/funder, who has granted bioRxiv a license to display the preprint in perpetuity. It is made available under aCC-BY-ND 4.0 International license.

12.09.2020

Intracellular Salmonella ultrastructural heterogeneity

110

111

112

113

114

115

116

117

118

119

120

121

122

123

124

125

126

127

128

129

130

131

132

133

134

\section{Results}

Bacterial cells rapidly respond to changing environments in order to adapt and to survive. We asked if different physiological states of bacteria are reflected by ultrastructural features. We reasoned that the bacterial response to different environments and to stressor or antimicrobial agents, may result in cells differing in their nanostructure.

\section{Ultrastructural diversity of Salmonella enterica cells in culture}

First, we applied conventional TEM with and without post-contrasting with heavy metals. STM WT was grown in Phosphate-Carbon-Nitrogen (PCN, (44)) minimal medium at pH 7.4 for $3.5 \mathrm{~h}$ for culture at reduced growth rate of 0.98 , compared to 1.33 in rich medium LB ( (41, 45). TEM analysis revealed that bacteria were very similar in ultrastructure, with a clearly visible outer and inner membrane separated by the periplasmic space (Figure 1A). The distance between the outer and inner membranes was $20 \pm 5 \mathrm{~nm}$ (mean $\pm \mathrm{SD}$ ). The center of cells, outlined by the inner membrane, was slightly electron dense with a difference of $135 \pm$ 16 in mean gray values (MGV) to the background, referred further as electron density. That region contained cytoplasm with protein complexes like ribosomes, visible as denser particles, which were distributed homogenously within the cell. Electron lucent and ribosomefree regions consisted of up to $16 \%$ of total cytoplasmic area and occupied not larger than 28 $\mathrm{nm}^{2}$ of area of clearly visible nucleoids. Hence, bacteria grown in the minimal PCN medium at physiological $\mathrm{pH}$ formed uniform populations of similar ultrastructure.

In addition, we analyzed the ultrastructure of STM cells cultured in PCN pH 7.4 medium supplemented with an amino acid (AA) mix (44) to increase the bacterial growth rate (Figure 1B). STM grown in PCN medium containing AA resembled bacteria grown in PCN medium without AA supplementation and formed a uniform bacterial population (Figure 1).

This was in contrast to bacteria grown in lysogeny broth (LB) as standard rich medium. If bacteria grown overnight in PCN medium were subcultured for $3.5 \mathrm{~h}$ in LB medium, cells 
bioRxiv preprint doi: https://doi.org/10.1101/2020.09.14.297432; this version posted September 17, 2020. The copyright holder for this preprint (which was not certified by peer review) is the author/funder, who has granted bioRxiv a license to display the preprint in perpetuity. It is made available under aCC-BY-ND 4.0 International license.

12.09 .2020

Intracellular Salmonella ultrastructural heterogeneity

with highly electron-dense cytoplasm were found, referred to as 'electron-dense' (ED) cells (arrowhead in Figure 1C), in addition to cells similar to these grown in PCN medium, referred to as 'electron-lucent' (EL) cells (asterisk in Figure 1C). If bacteria grown overnight in LB medium were subcultured for $3.5 \mathrm{~h}$ in LB medium, few EL cells (asterisk in Figure 1D) and numerous ED cells (arrowheads in Figure 1D) were detected. The averaged cytoplasmic electron density was $176 \pm 60 \mathrm{MGV}$ and $354 \pm 78 \mathrm{MGV}$ for EL and ED cells, respectively (Figure 1E). In addition, we quantified differences in the MGV of the bacterial cytoplasm and the background per image, revealing higher values of electron densities for ED cells independently in every frame (Figure S1A). Their averaged value (Figure S1B) was very similar to the mean of pooled data, with a significant difference of electron density between EL and ED cells (Figure 1E and S1B-C). Moreover, nanostructures as well as the periplasm were indistinguishable in ED cells, contrary to EL cell ultrastructure. Both cell types were visible during cell division as an evidence of their high viability (Figure 1D, arrows). In addition, in stationary LB cultures (Figure S1EG), we found some dying cells, with partially or completely loss of inner membranes, signs of molecular condensation (dark spots, arrows in Figure S1E), and/or lysis (the arrowhead in Figure S1G). These profiles also were frequent in STM WT of stationary PCN cultures, however, independently of medium $\mathrm{pH}$ or nutritional supplementations (Fig S1IKM). In $3.5 \mathrm{~h}$ subcultures of corresponding media, dying profiles were only sporadically found.

Hence depending on growth conditions, bacterial populations consist of either ultrastructural similar cells, or cells divergent in cytoplasmic electron densities.

\section{Controlled induction of STM ultrastructural diversity}

In order to find a correlation between ultrastructural types and environmental stress factors, we deployed a STM $\triangle \operatorname{sod} A B$ strain deficient in both cytoplasmic superoxide dismutases SodA and SodB. STM $\triangle \operatorname{sod} A B$ is especially sensitive to oxidative stress and turned out to be fragile, being able to grow in LB rich medium, but not in PCN minimal medium (41). Populations of 
bioRxiv preprint doi: https://doi.org/10.1101/2020.09.14.297432; this version posted September 17, 2020. The copyright holder for this preprint (which was not certified by peer review) is the author/funder, who has granted bioRxiv a license to display the preprint in perpetuity. It is made available under aCC-BY-ND 4.0 International license.

12.09.2020

Intracellular Salmonella ultrastructural heterogeneity

161

162

163

164

165

166

167

168

169

170

171

172

173

174

175

176

177

178

179

180

181

182

183

184

185

STM $\triangle \operatorname{sod} A B$ showed ED and EL cells with ultrastructural features as STM WT (Figure S1F-

$\mathrm{G}$ and $1 \mathrm{~F}$ ), however the EL cell type was dominant (Figure $1 \mathrm{G}-\mathrm{H}$, star). Next, we induced oxidative stress by adding methyl viologen ('paraquat', PQ), a redox-active compound producing superoxide. In the presence of PQ, STM $\triangle \operatorname{sod} A B$ expose to this toxic radical was prolonged. Treatment for $1 \mathrm{~h}$ with PQ at low concentrations of 1 or $5 \mu \mathrm{M}$ did not affect STM $\triangle \operatorname{sod} A B$ growth on agar plates (similar number colony forming units, CFU). TEM revealed that these treatments caused increase in frequency of ED cells (Figure 1I-L, arrowheads) in a dose-dependent manner, supporting its specificity to PQ treatment (Figure 1L). These results suggest that ED cells represent a type responding to cellular stress induced i.e. by ROS.

To further scrutinize the link between ultrastructure and cellular stress, we analyzed STM $\triangle \operatorname{sod} A B$ for abnormalities. STM $\triangle \operatorname{sod} A B$ showed abnormal colony growth on agar plates when compared to STM WT, forming evidently smaller colonies at comparable number (Figure 2AB). Slower colony growth could be a result of cell division defects, high level of cell death and/or just slower growth. As revealed by TEM, cells of STM $\triangle \operatorname{sodAB}$ were rodshaped and of similar size to STM WT without any signs of higher cellular death (Figure S1D-G). In addition, we assessed the membrane integrity using propidium iodide (PI) (Figure 2C-N). PI is a red-fluorescent dye binding to DNA, which is not membrane-permeable, thus DNA staining reports membrane damages (46). STM $\triangle \operatorname{sod} A B$ showed up to $5 \%$ of PI-positive cells at average without treatment (Figure 2C and S2), and even less PI-positive cells directly after incubation with 1 or $5 \mu \mathrm{M}$ PQ (Figure 2DFH and S2A). We performed PI staining again $12 \mathrm{~h}$ after PQ treatment and found high numbers of PI-positive cells in a group treated with $5 \mu \mathrm{M}$ PQ, suggesting membrane stress and initiation of progressive membrane injury (Figure 2EGH). Furthermore, ultrastructural analysis of STM $\triangle \operatorname{sod} A B$ revealed high number of cells with membrane invaginations. These were often asymmetrical, and single or multiple events occurred, which were differently located also including cell poles, therefore representing 
bioRxiv preprint doi: https://doi.org/10.1101/2020.09.14.297432; this version posted September 17, 2020. The copyright holder for this preprint (which was not certified by peer review) is the author/funder, who has granted bioRxiv a license to display the preprint in perpetuity. It is made available under aCC-BY-ND 4.0 International license.

12.09 .2020

Intracellular Salmonella ultrastructural heterogeneity

186

187

abnormal cell envelopes. These features were also present in $\triangle \operatorname{sod} A B$ without treatment, but increased after PQ treatment, suggesting oxidative stress as cause of this defect (Figure 2I-M, arrowheads). After treatment with $5 \mu \mathrm{M}$ PQ, high-resolution analysis revealed cell profiles with damaged inner and outer membranes, manifested by a loss of integrity and a leakage of cytoplasmic content, (Figure 2NO), in a line with PI analysis. Foci of lysis were also present after PQ treatment (asterisks in Figure 2LN). Hence, PQ treatment of STM $\triangle$ sodAB enhanced cellular stress and could be toxic to cells.

\section{Induction of ultrastructural heterogeneity of STM WT in PCN medium}

We confirmed that PQ concentrations higher than $50 \mu \mathrm{M}$ were potent to induce membrane stress in STM WT in a similar fashion as in $\triangle \operatorname{sodAB}$, significantly raising the number of PIpositive cells and PI fluorescence intensity (Figure S2B). Exposure to $50 \mu \mathrm{M} P Q$ achieved almost 70\% PI-positive cells directly after treatment (Figure S2A). As pathogenic bacterium, STM possesses multiple stress response systems that activate repair mechanisms to protect from oxidative stress, thus increasing the chance to survive PQ treatment (47). Therefore, we defined a toxic PQ concentration which reduced the number of viable STM, and analyzed the ultrastructure of STM WT after PQ treatment in various growth conditions (Figure S3). PCN medium at $\mathrm{pH} 5.8$ was also used to mimic the acidic phagosomal lumen of macrophages, where superoxide is protonated, capable to pass bacterial membranes but less spontaneously dismutates into hydrogen peroxide $(2,48)$. STM WT grown o/n in PCN medium at $\mathrm{pH} 7.4$ was inoculated in the same medium and grown further for 3.5 h. PQ treatments were always performed in PCN medium with reduced concentration of inorganic phosphate $\left(\mathrm{P}_{\mathrm{i}}\right)$ of 0.4 $\mathrm{mM}$, since $\mathrm{P}_{\mathrm{i}}$ could compete with PQ during transport through bacterial membranes (49). A shift from the growth medium to a medium of acidic $\mathrm{pH}$ had lesser impact on colony growth, in comparison to bacteria shifted to medium of $7.4 \mathrm{pH}, 96 \%$ of STM WT survived shift to $\mathrm{pH}$ 5.8, compared to shift to $\mathrm{pH}$ 7.4. After treatment with $100 \mu \mathrm{M} \mathrm{PQ}$, significant drop of survival 
bioRxiv preprint doi: https://doi.org/10.1101/2020.09.14.297432; this version posted September 17, 2020. The copyright holder for this preprint (which was not certified by peer review) is the author/funder, who has granted bioRxiv a license to display the preprint in perpetuity. It is made available under aCC-BY-ND 4.0 International license.

Intracellular Salmonella ultrastructural heterogeneity

to $20 \%$ or less of controls was observed at both $\mathrm{pH}$ values. Treatments with higher PQ concentrations such as $500 \mu \mathrm{M}$ or $1 \mathrm{mM}$, further reduced survival of STM WT, however, remained above $10 \%$ of controls (Figure S3W). TEM analysis of PQ-treated samples and

214 controls revealed that in all conditions bacterial cells were uniform in ultrastructural 215 appearance when cultured in $\mathrm{PCN}$ at $\mathrm{pH} 7.4$ or $\mathrm{pH} 5.8$ without AA supplementation (Figure $2163 \mathrm{AB}$ and S3A-F). After PQ treatment, the cytoplasm was denser but ultrastructures like inner 217 membranes, ribosomes or DNA were easily distinguishable. We did not find ED cells and we 218 also did not find many cells with profiles of ultrastructural abnormalities (Figure S3A-L). It is 219 possible that in PCN medium with limited nutrients, bacteria were not capable to switch to an 220 emergency mode after PQ treatment, what would explain absence of ED cells and poor 221 growth on agar plates.

222 To test this hypothesis, we performed the same experiments in PCN medium supplemented 223 with AA (Figure 3C-F). STM survival after $1 \mathrm{mM}$ PQ treatment was only higher when 224 cultured in PCN medium pH 7.4 supplemented with AA, in contrast to STM grown without 225 AA, or in PCN medium with a pH of 5.8 (Figure 3G). This was in line with the presence or 226 lack of bacteria with ED type. ED cells emerged only in PCN pH 7.4 medium when 227 supplemented with AA (Figure 3D). Treatments with lower PQ concentrations did not affect 228 STM ultrastructure in PCN medium supplemented with AA (Figure S3M-O). For comparison, 229 we also investigated the impact of other stress conditions on STM ultrastructure (Figure S3P230 V). ED type was not observed after an osmotic shock or heat shock. It occurred after acid 231 shock (shift to $\mathrm{pH}$ 3.0) of STM subcultured in PCN, pH 7.4 with AA supplementation, but not 232 after subculture in PCN, pH 5.8. We observed other ultrastructural features, which were 233 shock-specific to respective shock conditions and never observed in bacteria of control 234 cultures. We compared presence of bacteria with shrinkage and/or lysis features since such 235 profiles were observed in normal growth conditions (Figure S3Y). Cells with shrinkage 236 and/or lysis features dominated the population after hyper osmotic stress in presence of 
bioRxiv preprint doi: https://doi.org/10.1101/2020.09.14.297432; this version posted September 17, 2020. The copyright holder for this preprint (which was not certified by peer review) is the author/funder, who has granted bioRxiv a license to display the preprint in perpetuity. It is made available under aCC-BY-ND 4.0 International license.

12.09.2020

Intracellular Salmonella ultrastructural heterogeneity

$600 \mathrm{mM} \mathrm{NaCl}$ (shrinkage: 82.8 -fold increase compared to untreated and $74.6 \%$ of total cells; lysis: 18.7-fold increase compared to untreated, 16.9\% of total) (Figure S3U). Obvious increase of STM with signs of shrinkage and/or lysis was also observed after $\mathrm{pH}$ shock $(\mathrm{pH}$ 3.0) and was more pronounced when cells were subcultured at neutral $\mathrm{pH}$. Simultaneous treatment with $1 \mathrm{mM}$ PQ during $\mathrm{pH}$ shock resulted in comparable frequencies, suggesting only minor or no impact of PQ on causing shrinkage or lysis. This was in line with a low frequency of signs of shrinkage and/or lysis $(<10 \%)$ after PQ treatment in all other tested conditions (Figure S3Y) Hence, occurrence of ED type is induced by environmental stress and requires presence of $\mathrm{AA}$.

\section{Ultrastructural diversity of intracellular STM}

STM is able to replicate within eukaryotic cells where it encounters host cell defense mechanisms, as well as harsh phagosomal environments and nutritional limitations $(40,50)$. To correlate the ultrastructural features to intracellular phenotypes, we examined the ultrastructure of STM in HeLa cells at $8 \mathrm{~h}$ or $16 \mathrm{~h}$ post infection (p.i.). At both time points, host cells were either intact, with or without intracellular STM, or dying and ruptured as result of bacterial hyper-replication. Within healthy host cells, we found EL STM WT as well as mixed populations with EL and ED cells similarly to STM in LB medium (Figure 4). Both types were located within SCVs and showed signs of cell division. These data confirmed that ultrastructural EL and ED types are natural morphotypes of STM.

\section{Metabolic activity of intracellular STM}

In order to test vitality and biosynthetic capability of distinct morphotypes of STM, we used an episomal encoded dual-color fluorescence reporter (Figure S4A) (51). Bacteria harboring the reporter constitutively express $g f p$. To report viability and biosynthetic capacity, we monitored dsred expression regulated by the anhydrotetracycline (AHT)-inducible tetA promoter (52). We considered cells as biosynthetic active when DsRed was detected after AHT induction. 
bioRxiv preprint doi: https://doi.org/10.1101/2020.09.14.297432; this version posted September 17, 2020. The copyright holder for this preprint (which was not certified by peer review) is the author/funder, who has granted bioRxiv a license to display the preprint in perpetuity. It is made available under aCC-BY-ND 4.0 International license.

12.09.2020

Intracellular Salmonella ultrastructural heterogeneity

263 First, we tested reporter functionality by flow cytometry (Figure S4BCD). STM WT

264 harboring the reporter was subcultured to late-logarithmic growth phase in LB medium. AHT

265 was added after $3 \mathrm{~h}$ of growth, with or without chloramphenicol $(\mathrm{Cm})$ to inhibit protein

266 biosynthesis DsRed-positive cells were already detected 0.5-1 h after AHT induction. DsRed

267 fluorescence intensity increased rapidly at 1.5-3 h post induction. Without AHT induction, or

268 AHT induction in presence of $\mathrm{Cm}$, no DsRed-positive cells were detected, verifying that

269 inducible expression of $d s r e d$ can be used as a marker for biosynthetic capability (Figure

270 S4CD). We were also able to visualize metabolically active STM by live-cell fluorescence

271 microscopy (FM) of infected host cells, supporting that the reporter can be used to study the

272 metabolic status of intracellular STM (Figure S4E). We investigated infected HeLa LAMP1-

273 GFP cells $8 \mathrm{~h}$ or $16 \mathrm{~h}$ p.i. (Figure 5). The intracellular population was heterogeneous based on

274 protein synthesis and divergent when compared between infected host cells consisting of

275 either only metabolically active or mixed metabolically active and inactive STM.

276 Previous TEM analysis showed that host cell viability decreased when containing high burden

277 of intracellular bacteria. Using LAMP1-GFP as marker we could assess Salmonella-induced

278 endosomal remodeling (Figure 5A). We also observed lack of these compartments (Figure

279 5B) possibly due to activation of death processes in the host or due to their rupture by

280 escaping STM into the host cell cytoplasm. Presence of individual metabolically inactive

281 STM within a population of metabolically active STM raised the possibility that inactive

282 STM are viable. Bacteria may form persisters with ceased growth, highly reduced

283 metabolism, and ability to return to normal growth after release from stressful conditions. To

284 scrutinize the bacterial conditions in host cells further, we applied correlative light and

285 electron microscopy (CLEM).

\section{CLEM with the dual-color reporter strains}

287 We modified a previous CLEM approach to accelerate data collection and further applied

288 deconvolution of FM data (Figure S5) (53). We observed intracellular STM populations 
bioRxiv preprint doi: https://doi.org/10.1101/2020.09.14.297432; this version posted September 17, 2020. The copyright holder for this preprint (which was not certified by peer review) is the author/funder, who has granted bioRxiv a license to display the preprint in perpetuity. It is made available under aCC-BY-ND 4.0 International license.

12.09.2020

Intracellular Salmonella ultrastructural heterogeneity

consisting of ED and EL cell types (72.7\% ED cell type, 27.2\% EL cell type), which were also visualized during cell division (Figure 6A, Ac). Highly electron-lucent single bacteria were found just once per ROI showing clearly visible outer membrane, outlined periplasm, and produced DsRed at high level (Figure 6Ad, Ba-b). However, there was no strict correlation of metabolically active, less active, or non-active STM with any of electron density-based morphotypes. We found both, ED and EL types strongly (34.4\% of ED and $41.7 \%$ of EL) or slightly (18.8\% of ED and $16.7 \%$ of EL) marked for DsRed expression. In addition, $46.9 \%$ of ED and $41.7 \%$ of EL cells showed metabolic inactivity. In ROIs with high numbers of STM, we detected clear differences in bacterial size, with an area of $1.76 \pm 0.25$ $\mu \mathrm{m}^{2}$ (wide) or $0.96 \pm 0.18 \mu \mathrm{m}^{2}$ (thin), which were only partially correlated with the electron density type (Figure 6A). Interestingly, size-based classes were rather grouped in the host cell with 'wide' STM located more centrally and 'thin' STM located on the cell peripheries (Figure 6A). Thin STM were highly metabolically active, while ED wide cells had no or minor expression of DsRed, localized to small patches. Dividing STM of both, ED and EL types, were wide and less metabolically active. Some bacteria were devoid of SCV and located in the host cell cytoplasm (Figure 6Ac). Complete SCV or SIF were not present, in line with lack of LAMP1-GFP signal. Contrary, lysosomes, endosomes and autophagic structures were present in a region with many thin and metabolically active STM, however, were not visible within degradative organelles.

All together, these data provide further evidence for the existence of different ultrastructural classes. Furthermore, we found STM cells with special features (Figure 7). It had clear condensations of structures in the cytoplasm with a dense layer surrounding loose materials in the center (halo-like condensation). Correlation of fluorescence signals with the ultrastructural profile showed that the 'halo'-like electron density contained GFP and DsRed. The biosynthetic activity of this cell was at high level, suggesting high vitality. At the poles, lucent 
bioRxiv preprint doi: https://doi.org/10.1101/2020.09.14.297432; this version posted September 17, 2020. The copyright holder for this preprint (which was not certified by peer review) is the author/funder, who has granted bioRxiv a license to display the preprint in perpetuity. It is made available under aCC-BY-ND 4.0 International license.

12.09.2020

Intracellular Salmonella ultrastructural heterogeneity

314 blebs of regular size and shape were visible suggesting that they were not lysis spots. The

315 inner bacterial membrane in proximity of lucent blebs was intact (Figure 7BC).

316 Hence, the CLEM approach had sufficient resolution to visualize distinct DsRed/GFP

317 distributions inside bacteria in correlation with the ultrastructure.

\section{The 'halo' type of bacteria}

319 We noticed presence of STM with halo-like condensations in the cytoplasm also in o/n LB

320 cultures, what allowed for quantifications of this type. Cells with halo-like condensation had centrally located lucent region, occupying $39-55 \%$ of the whole cell area $(48.5 \% \pm 4.9)$.

Quantification revealed that cultures in late-logarithmically growth did not contain any cells

with halo-like condensations, in contrast to stationary cultures (o/n) (Figure 8A). Moreover,

the $\triangle \operatorname{sod} A B$ strain more frequently formed halo-like structures, suggesting a link between stress and 'halo' ultrastructure (Figure 8A). In contrast, we did not detect halo-like condensations in any STM cell cultured in PCN medium, independently of growth phase, $\mathrm{pH}$,

AA supplementation, or even shock conditions.

We further tested to induce experimentally the appearance of the halo-like type. UV light of wavelengths of 290-320 nm (UVB), or $254 \mathrm{~nm}$ (UVC) are highly bactericidal (54). Therefore,

STM WT cultured in LB medium was analyzed by TEM after UV treatment, which resulted in complete lack of colony growth on agar plates (Figure 8B-C and S6A-E). The ultrastructural profiles of UV-treated STM were classified, revealing reduced numbers of EL type when compared to untreated cells. ED profiles were slightly more frequent, together with

334 profiles showing signs of cellular death. UV treatment induced formation of the halo-like type to almost the frequency observed for STM $\triangle \operatorname{sodAB}$ (Figure 8ABC, arrowhead). Hence, there

336 is a correlation of the halo-like type frequency with occurrence of cell death induced by UV 337 illumination.

338 We also determined biosynthetic capacity after UV treatment and found significant reduction 
bioRxiv preprint doi: https://doi.org/10.1101/2020.09.14.297432; this version posted September 17, 2020. The copyright holder for this preprint (which was not certified by peer review) is the author/funder, who has granted bioRxiv a license to display the preprint in perpetuity. It is made available under aCC-BY-ND 4.0 International license.

Intracellular Salmonella ultrastructural heterogeneity

340 while no colony growth was observed (Figure S6EF). We analyzed infected host cells with

341 respect to presence of halo-like morphotype and found that this type dominated intracellular

342 populations in case of hyper-replication, when bacteria were leaving the host, or host cells

343 were necrotic (Figure 8D-I, arrowheads). In infection experiments, the antibiotic gentamicin

344 is used to kill extracellular bacteria, while intracellular bacteria are protected. We tested if

345 gentamicin could be a cause for the increase of the halo-like type in infection experiments,

346 however, treatment of STM cultures with gentamicin did not recapitulate this result (data not

347 shown).

348 After growth in rich media like LB cultures, halo-like morphotype was about 10\%, suggesting

349 low exposure to cell-damaging agents. Within host cells, the impact on ultrastructural

350 characteristics of STM was more dramatic. Taken together, these results demonstrate that the

351 halo-like type could be an indicator of exposure of STM to critical environmental conditions. 
bioRxiv preprint doi: https://doi.org/10.1101/2020.09.14.297432; this version posted September 17, 2020. The copyright holder for this preprint (which was not certified by peer review) is the author/funder, who has granted bioRxiv a license to display the preprint in perpetuity. It is made available under aCC-BY-ND 4.0 International license.

12.09.2020

Intracellular Salmonella ultrastructural heterogeneity

353

\section{Discussion}

In this work, we present evidence that several morphotypes of viable bacteria exist. Based on ultrastructural criteria, these morphotypes differ significantly in cytoplasmic electron density, which is well distinguishable at low EM resolution (1,000-2,000-fold magnification, $50 \mathrm{keV})$, as well as in organization and visibility of defined (chromosome, ribosomes) and undefined structures (dense cytoplasmic areas). We present EL and ED types of STM, representing viable bacteria active for protein biosynthesis and/or able to divide. The frequency of morphotypes in a bacterial population can be used as an indicator of environmental changes, what in turn enables new ways of EM data interpretation. Moreover, ultrastructural heterogeneity is not limited to Salmonella enterica, since published TEM micrographs of other bacteria demonstrate morphotypes similar to EL, ED, as well as halo-like type. These types seem to be neither restricted to Gram-negative nor pathogenic bacteria. Their examples have been visualized intracellular in both, cell cultures and infected animals previously, and were not restricted to mammalian cells (22-34). However, the nature or function of the ultrastructural diversity remained enigmatic.

Here, we provide evidence that the ultrastructural heterogeneity, other than death-related, is associated with environmental changes. We further demonstrated that the external AA supplementation is required for ED induction and that the oxidative stress-dependent formation of ED bacteria only takes place in nutrient-rich medium. In contrast, ED cells were hardly inducible by oxidative stress in minimal media, which did not contain AA. Furthermore, induction of ED type is $\mathrm{pH}$ sensitive with restriction to a phagosomal $\mathrm{pH}$. Consistently with weak survival capabilities, the lack of obvious ED type in PCN medium despite oxidative stress, may reflect difficulties of cells to respond properly. Recently, a morphotype reminiscent with ED has been described in E. coli, as representative of healthy cells $(12,55)$. In addition, we have identified the very characteristic halo-like type, which dominates bacterial populations exposed to extreme conditions. This type occurred 
bioRxiv preprint doi: https://doi.org/10.1101/2020.09.14.297432; this version posted September 17, 2020. The copyright holder for this preprint (which was not certified by peer review) is the author/funder, who has granted bioRxiv a license to display the preprint in perpetuity. It is made available under aCC-BY-ND 4.0 International license.

12.09.2020

Intracellular Salmonella ultrastructural heterogeneity

sporadically in stationary phase and is increased in cultures after bactericidal UV treatment, pointing to its link with deadly noxes. CLEM analysis of halo-like type suggests that the dense matter around the DNA-containing center is of proteinaceous nature since GFP and DsRed were located within this area. At this moment we do not know the underlying mechanisms of different cytoplasmic states at the ultrastructural level but one possible explanation for ED type can be macromolecular crowding as a result of stress response (56, 57). Previously, molecular crowding has been demonstrated in E. coli after osmotic up-shift, affecting diffusion of GFP. These changes were accompanied by dramatic cytoplasmic shrinkage, which was only sporadically observed at the cell poles by TEM in our experiments $(58,59)$.

Global and dramatic ultrastructural alterations of bacteria occurred very fast, because differences were visible by TEM when cells were fixed directly after stress treatment. On the other side, dead and dying bacterial cells, according to ultrastructural criteria like membrane injuries, lysis, and/or leakage of content are not frequent, even after bactericidal UV applications or after shock conditions. This suggests that STM can be alive for a long time without being capable to form colonies. We also visualized cells at high resolution to clearly discriminate between lysis and storage granules or other electron-lucent components not related with death (this study; 19, 58), and between molecular condensation and protein-based organelles like carboxisomes $(19,60)$. Except ruptures and detachments, membrane waving and surface protrusions cannot be interpreted with convenience as indicators of deadly membrane stress, since they may reflect adaptive activity of cells, i.e. changes in membrane fluidity or vesicle formation (61-66). Criteria for dying cells were found in EL, ED and halolike type, exhibiting severity stages as intermediates of death processes, different cellular location and mix of criteria.

Taken together, our study sheds more light on ultrastructural heterogeneity of STM and revealed possible EM indicators, which allow to broaden EM data interpretation. Since the 
bioRxiv preprint doi: https://doi org/10.1101/2020.09.14.297432; this version posted September 17, 2020. The copyright holder for this preprint (which was not certified by peer review) is the author/funder, who has granted bioRxiv a license to display the preprint in perpetuity. It is made available under aCC-BY-ND 4.0 International license.

Intracellular Salmonella ultrastructural heterogeneity

405 ED type could serve as indicator for oxidative stress, and the halo-like type as an indicator for

406 hazardous environmental conditions, future research infection in biology will benefit, because

407 these indicators may be used when detailed analyses are difficult or impossible. For example,

408 when bacterial populations in vivo in deep tissues are investigated or populations not

409 compatible with reporter systems are analyzed as for example free-living microorganisms,

410 which were directly analyzed without cultivation.

411

412 Acknowledgements

413 This work was supported by the DFG by grant P15 and the Z project in SFB 944. The

414 excellent technical assistance of Birgit Hemmis and Britta Brickwedde is kindly 415 acknowledged.

416 
bioRxiv preprint doi: https://doi org/10.1101/2020.09.14.297432; this version posted September 17, 2020. The copyright holder for this preprint (which was not certified by peer review) is the author/funder, who has granted bioRxiv a license to display the preprint in perpetuity. It is made available under aCC-BY-ND 4.0 International license.

12.09.2020

Intracellular Salmonella ultrastructural heterogeneity

\section{Materials and Methods}

\section{Bacterial strains and growth conditions}

Salmonella enterica serovar Typhimurium strain NCTC12023 (STM) was used as wild-type

strain and isogenic strain MvP2400 ( $\Delta \operatorname{sodA}::$ FRT $\Delta \operatorname{sodB}::$ FRT) has been described (41).

(for paraquat treatment) or $25 \mathrm{mM} \mathrm{PO}_{4}^{-}(44,45)$ at $\mathrm{pH}$ of 5.8 or 7.4 at $37{ }^{\circ} \mathrm{C}$ with aeration.

Optionally, medium was supplemented with an $1 \mathrm{x}$ mix of 20 amino acids (alanine $(0.8 \mathrm{mM})$,

arginine $(5.2 \mathrm{mM})$, asparagine $(0.4 \mathrm{mM})$, aspartate $(0.4 \mathrm{mM})$, cysteine $(0.1 \mathrm{mM})$, glutamic acid $(0.6 \mathrm{mM})$, glutamine $(0.6 \mathrm{mM})$, glycine $(0.8 \mathrm{mM})$, histidine $(0.2 \mathrm{mM})$, isoleucine $(0.4$

proline $(0.4 \mathrm{mM})$, serine $(10.0 \mathrm{mM})$, threonine $(0.4 \mathrm{mM})$, tryptophan $(0.1 \mathrm{mM})$, tyrosine $(0.2$

$\mathrm{mM})$, valine $(0.6 \mathrm{mM}))(44)$. When required, carbenicillin or chloramphenicol were added at

$50 \mu \mathrm{g} \mathrm{x} \mathrm{ml}^{-1}$ or $200 \mu \mathrm{g} \mathrm{x} \mathrm{ml} \mathrm{l}^{-1}$, respectively. For live cell imaging and flow cytometry analysis

of bacterial metabolic activity, the strains harbored plasmid pWRG658 ( $\mathrm{P}_{r p s M}::$ gfpmut3A tetR

$\mathrm{P}_{\text {tetA }}::$ dsRed T3_S4T) (51) for constitutive expression of $g f p$ and AHT-inducible expression of

dsred.

\section{AHT induction}

AHT (Fluka, Sigma-Aldrich) stock solutions were stored in aliquots of $200 \mu \mathrm{g} \mathrm{x} \mathrm{ml}{ }^{-1}$ in dimethylformamide (DMF) at $-20{ }^{\circ} \mathrm{C}$ in the dark. For induction of expression of the $\mathrm{P}_{\text {tetA }}{ }^{-}$ controlled dual-color vitality sensor, AHT was added directly to LB broth or cell culture medium to a concentration of $100 \mathrm{ng} \mathrm{x} \mathrm{ml}^{-1}$ as indicated.

\section{Propidium iodide staining of STM}

439 Propidium iodide (PI) (Sigma-Aldrich) was used as described (67) to analyze cell envelope 440 integrity at a concentration of $30 \mu \mathrm{M}$ in PBS. STM was cultured as indicated, PI was added, 441 and incubated for $10 \mathrm{~min}$ in the dark. Subsequently, bacteria were washed twice by 
bioRxiv preprint doi: https://doi org/10.1101/2020.09.14.297432; this version posted September 17, 2020. The copyright holder for this preprint (which was not certified by peer review) is the author/funder, who has granted bioRxiv a license to display the preprint in perpetuity. It is made available under aCC-BY-ND 4.0 International license.

12.09.2020

Intracellular Salmonella ultrastructural heterogeneity

442

443

centrifugation $(5,000 \mathrm{x} \mathrm{g}, 5 \mathrm{~min})$ in the same buffer, $5 \mu \mathrm{l}$ of diluted bacteria were put on a glass slide, covered with a cover slip and imaged by the Zeiss LSM (Zeiss).

\section{Stress induction by methyl viologen, heat, hyper- or hypo-osmolarity}

STM strains were cultured overnight as indicated, diluted 1:31 in fresh medium, subcultured for further $3.5 \mathrm{~h}$, shifted to fresh PCN medium as indicated and exposed to methyl viologen (Sigma-Aldrich) for $1 \mathrm{~h}$ at RT without shaking, to $80{ }^{\circ} \mathrm{C}$ (in $\mathrm{PCN}$ medium $\mathrm{pH} 7.4$ ) or to hyper-osmolar (PCN medium pH 7.4 containing $600 \mathrm{mM} \mathrm{NaCl}$ ) or hypo-osmolar conditions (pure $\mathrm{H}_{2} \mathrm{O}_{\mathrm{dd}}$ ) for $2 \mathrm{~h}$. Effect of methyl viologen was confirmed by plating of bacteria onto LB plates. Subsequently, bacteria were processed for PI staining or TEM as described above or below, respectively.

\section{UV inactivation of STM}

Overnight cultures of STM were grown in LB broth, normalized to an $\mathrm{OD}_{600}$ of 0.2 in PBS and transferred to a petri dish following irradiation with UV light $(305 \mathrm{~nm})$ for $60 \mathrm{sec}$. Successful UV inactivation was always confirmed by plating of inactivated bacterial suspension onto LB plates. If indicated, inactivated bacteria were processed for EM as described below.

\section{Flow cytometry analysis}

Overnight cultures of STM were grown in LB broth, diluted 1:31 in fresh LB and subcultured for further $6 \mathrm{~h}$. At indicated time points, samples were taken, diluted in PBS and directly subjected to flow cytometry without fixation. Flow cytometry was performed on an Attune NxT instrument (ThermoFischer Scientific) at a flow rate of $25 \mu 1 \times \mathrm{min}^{-1}$. At least 50,000 bacteria were gated by virtue of the constitutive GFP fluorescence. The percentage of DsRedpositive bacteria was determined, the intensity of the DsRed fluorescence per gated STM cell was recorded and X-medians for DsRed intensities were calculated. 
bioRxiv preprint doi: https://doi org/10.1101/2020.09.14.297432; this version posted September 17, 2020. The copyright holder for this preprint (which was not certified by peer review) is the author/funder, who has granted bioRxiv a license to display the preprint in perpetuity. It is made available under aCC-BY-ND 4.0 International license.

12.09.2020

Intracellular Salmonella ultrastructural heterogeneity

467 For infection experiments the non-polarized epithelial cell line HeLa (American Type Culture

468 Collection, ATCC no. CCL-2) stably transfected with LAMP1-GFP was used. HeLa cells 469 were cultured in Dulbecco's modified Eagle's medium (DMEM) containing $4.5 \mathrm{~g} \times \mathrm{l}^{-1}$

470 glucose, $4 \mathrm{mM}$ stable glutamine and sodium pyruvate (Biochrom) and supplemented with $47110 \%$ inactivated fetal calf serum (iFCS) (Sigma-Aldrich) at $37{ }^{\circ} \mathrm{C}, 5 \% \mathrm{CO}_{2}$ and $90 \%$ 472 humidity.

\section{Host cell infection}

474 For infection of HeLa LAMP1-GFP cells, Salmonella strains were grown overnight in LB 475 broth, diluted 1:31 in fresh LB and subcultured for further $3.5 \mathrm{~h}$ to induce maximal 476 invasiveness. Infection was performed with a multiplicity of infection (MOI) of 50 for $25 \mathrm{~min}$ 477 at $37{ }^{\circ} \mathrm{C}, 5 \% \mathrm{CO}_{2}$ and $90 \%$ humidity. Subsequently, cells were washed thrice with PBS and 478 incubated for $1 \mathrm{~h}$ with medium containing $100 \mathrm{mg} \mathrm{x} \mathrm{ml}^{-1}$ gentamicin (Applichem) to kill all 479 non-invaded bacteria. Afterwards, the medium was replaced by medium containing $10 \mathrm{mg} \mathrm{x}$ $480 \mathrm{~mL}^{-1}$ gentamicin until the end of the experiment.

\section{Live cell imaging and image deconvolution}

482 For live cell imaging, DMEM was replaced by imaging medium consisting of Minimal 483 Essential Medium (MEM) with Earle's salts, without $\mathrm{NaHCO}_{3}$, without L-glutamine and 484 without phenol red (Biochrom) supplemented with $30 \mathrm{mM}$ HEPES (4-(2-hydroxyethyl)- 1485 piperazineethanesulfonic acid) (Sigma-Aldrich) with a $\mathrm{pH}$ of 7.4. For imaging of fixed cells, 486 cells were washed thrice with PBS and incubated for 15 min with PBS containing 3\% para487 formaldehyde (PFA) to ensure complete fixation of cells. Subsequently, cells were washed 488 thrice with PBS and blocked with blocking solution containing $2 \%$ bovine serum albumin and $4892 \%$ goat serum in PBS. Fluorescence imaging was performed using the confocal laser490 scanning microscope (CLSM) Leica SP5. For setting adjustment, image acquisition and 491 image processing the software LAS AF (Leica, Wetzlar, Germany) was used. Image 
bioRxiv preprint doi: https://doi.org/10.1101/2020.09.14.297432; this version posted September 17, 2020. The copyright holder for this preprint (which was not certified by peer review) is the author/funder, who has granted bioRxiv a license to display the preprint in perpetuity. It is made available under aCC-BY-ND 4.0 International license.

12.09.2020

Intracellular Salmonella ultrastructural heterogeneity

492

493

494

495

496

497

498

499

500

501

502

503

504

505

506

507

508

509

510

511

512

513

514

515

516

517

acquisition was performed using objectives 10x (HC PL FL 10x, NA 0.3), 20x (HC PL APO

CS 20x, NA 0.7), 40x (HCX PL APO CS 40x, NA 1.25-0.75) and 100x objective (HCX PL APO CS 100x, NA 1.4-0.7) (Leica, Wetzlar, Germany) and the polychromic mirror TD 488/543/633 for the three channels GFP, DsRed and DIC. For CLEM experiments, images were further deconvoluted using Huygens software (Scientific Volume Imaging B.V., Hilversum, The Netherlands) to better correlate the expression patterns of DsRed to the bacterial ultrastructure. Live cell imaging was performed using the Zeiss Cell Observer microscope with Yokogawa Spinning Disc Unit CSU-X1a, Evolve EMCCD camera (Photometrics, USA) and live cell periphery, equipped with an Alpha Plan-Apochromat 63x (NA 1.46) oil immersion objective (Zeiss, Oberkochen, Germany). Following filter combinations were used for image acquisition: GFP with BP 525/50, DsRed with LP 580 and processed by the ZEN 2012 (Zeiss, Oberkochen, Germany) software. Scale bars for all acquired images were added with Photoshop CS6 (Adobe).

\section{Sample preparation for TEM}

STM cultured either in LB or PCN medium were fixed with $2.5 \%$ glutaraldehyde (GA) (Electron Microscopy Science) in $100 \mathrm{mM}$ phosphate buffer $\left(81.8 \mathrm{mM} \mathrm{Na} 2 \mathrm{HPO}_{4}\right.$ and 18.2 $\mathrm{mM} \mathrm{KH} \mathrm{KO}_{4}, \mathrm{pH} 7.2$ ) over night at $4{ }^{\circ} \mathrm{C}$. Unreacted aldehydes were blocked with $100 \mathrm{mM}$ glycine in buffer for $15 \mathrm{~min}$. Osmification was performed with $1 \%$ osmium tetroxide (Electron Microscopy Science) in $100 \mathrm{mM}$ phosphate buffer for $60 \mathrm{~min}$ on ice following washing several times with phosphate buffer and ultrapure water (MilliQ). Subsequently, contrasting with $1 \%$ uranyl acetate (Electron Microscopy Science) in MilliQ for 30 min was performed following several washing steps. Afterwards, cells were dehydrated in a cold graded ethanol series finally rinsing once in anhydrous ethanol and twice in anhydrous acetone at room temperature. Infiltration was performed in mixes of acetone and EPON812 (Serva). After every incubation or washing step bacteria were centrifuged (2000 x g, 3 min), the supernatant was discarded followed by the next preparation step. 
bioRxiv preprint doi: https://doi org/10.1101/2020.09.14.297432; this version posted September 17, 2020. The copyright holder for this preprint (which was not certified by peer review) is the author/funder, who has granted bioRxiv a license to display the preprint in perpetuity. It is made available under aCC-BY-ND 4.0 International license.

12.09.2020

Intracellular Salmonella ultrastructural heterogeneity

\section{Sample preparation for CLEM}

519 Two days prior to infection HeLa LAMP1-GFP cells $\left(1 \times 10^{5}\right)$ were seeded onto a gridded coverslip in a petri dish (MatTek, Ashland, MA). $14 \mathrm{~h}$ p.i. $100 \mathrm{ng} \mathrm{x} \mathrm{ml}^{-1}$ AHT was added to

521 the cells for induction of reporter plasmid. $16 \mathrm{~h}$ p.i. cells were pre-fixed with pre-warmed 2.5\% GA in $0.1 \mathrm{M}$ phosphate buffer for $15 \mathrm{~min}$ at $37{ }^{\circ} \mathrm{C}$. After washing the cells thrice with

PBS, ROIs were documented and images were acquired. Subsequently, further fixation was

524 performed using $2.5 \% \mathrm{GA}$ in $0.1 \mathrm{M}$ phosphate buffer over night at $4{ }^{\circ} \mathrm{C}$. Quenching, osmification and contrasting was performed as described above. Then, the gridded coverslip dehydrated in a cold graded ethanol series, finally rinsing once in anhydrous ethanol and twice in anhydrous acetone at room temperature. Infiltration and flat-embedding were performed in mixes of acetone and EPON812 (Serva). During the removal of the gridded coverslip from the polymerized EPON the engraved coordinates were transferred to the EPON surface and allowed easy relocation by microscopy. ROIs were cut using a scalpel and were transferred to an EPON block. Serial $200 \mathrm{~nm}$ sections were generated by an ultramicrotome (Leica EM UC7) and collected on formvar-coated copper EM slot grids.

\section{Transmission electron microscopy}

535 High-resolution analysis including CLEM was performed using the Libra 120 TEM (Zeiss, 536 Oberkochen, Germany) operating at $120 \mathrm{keV}$ and equipped with an Omega energy filter and a 2,000×2,000-pixel digital camera (Troendle). In addition, TEM was performed using a Zeiss 538902 system (Zeiss, Oberkochen, Germany) operating at $50 \mathrm{keV}$. Images were taken with the 539 software ImageSP (TRS image SysProg, Moorenwies, Germany). TEM micrographs were 540 adjusted for brightness and contrast enhanced using ImageJ or Photoshop software when 541 necessary. For image analysis, software ImageJ (http://rsbweb.nih.gov/ij/) was used. Stitching 542 and overlay of CLSM and TEM images were done using Photoshop CS6 (Adobe). 
bioRxiv preprint doi: https://doi.org/10.1101/2020.09.14.297432; this version posted September 17, 2020. The copyright holder for this preprint (which was not certified by peer review) is the author/funder, who has granted bioRxiv a license to display the preprint in perpetuity. It is made available under aCC-BY-ND 4.0 International license.

12.09.2020

Intracellular Salmonella ultrastructural heterogeneity

\section{References}

545 1. Avraham R, Haseley N, Brown D, Penaranda C, Jijon HB, Trombetta JJ, Satija R,

546

547

548

549

550

551

552

553

554

555

556

557

558

559

560

561

562

563

564

565

566

567

568

569

570

571

572

573

574

575

576

577

578

579

580

581

582

583

584

585

586

587

588

589

590

591
Shalek AK, Xavier RJ, Regev A, Hung DT. 2015. Pathogen Cell-to-Cell Variability Drives Heterogeneity in Host Immune Responses. Cell 162:1309-1321.

2. Burton NA, Schürmann N, Casse O, Steeb AK, Claudi B, Zankl J, Schmidt A, Bumann D. 2014. Disparate impact of oxidative host defenses determines the fate of Salmonella during systemic infection in mice. Cell Host and Microbe 15:72-83.

3. Claudi B, Spröte P, Chirkova A, Personnic N, Zankl J, Schürmann N, Schmidt A, Bumann D. 2014. Phenotypic variation of Salmonella in host tissues delays eradication by antimicrobial chemotherapy. Cell 158:722-733.

4. Helaine S, Cheverton AM, Watson KG, Faure LM, Matthews SA, Holden DW. 2014. Internalization of Salmonella by macrophages induces formation of nonreplicating persisters. Science 343:204-8.

5. Brenzinger S, van der Aart LT, van Wezel GP, Lacroix JM, Glatter T, Briegel A. 2019. Structural and Proteomic Changes in Viable but Non-culturable Vibrio cholerae. Front Microbiol 10:793.

6. Khodaparast L, Khodaparast L, Gallardo R, Louros NN, Michiels E, Ramakrishnan R, Ramakers M, Claes F, Young L, Shahrooei M, Wilkinson H, Desager M, Mengistu Tadesse W, Nilsson KPR, Hammarstrom P, Aertsen A, Carpentier S, Van Eldere J, Rousseau F, Schymkowitz J. 2018. Aggregating sequences that occur in many proteins constitute weak spots of bacterial proteostasis. Nat Commun 9:866.

7. Lidstrom ME, Konopka MC. 2010. The role of physiological heterogeneity in microbial population behavior. Nat Chem Biol 6:705-12.

8. Fang FC, Frawley ER, Tapscott T, Vazquez-Torres A. 2016. Bacterial Stress Responses during Host Infection. Cell Host Microbe 20:133-43.

9. Fisher RA, Gollan B, Helaine S. 2017. Persistent bacterial infections and persister cells. Nat Rev Microbiol 15:453-464.

10. LaRock DL, Chaudhary A, Miller SI. 2015. Salmonellae interactions with host processes. Nat Rev Microbiol 13:191-205.

11. Konopka MC, Sochacki KA, Bratton BP, Shkel IA, Record MT, Weisshaar JC. 2009. Cytoplasmic protein mobility in osmotically stressed Escherichia coli. J Bacteriol 191:231-7.

12. Wood TK, Song S, Yamasaki R. 2019. Ribosome dependence of persister cell formation and resuscitation. J Microbiol 57:213-219.

13. Parry BR, Surovtsev IV, Cabeen MT, O'Hern CS, Dufresne ER, Jacobs-Wagner C. 2014. The bacterial cytoplasm has glass-like properties and is fluidized by metabolic activity. Cell 156:183-94.

14. Golding I, Cox EC. 2006. Physical nature of bacterial cytoplasm. Phys Rev Lett 96:098102.

15. Yeates TO, Crowley CS, Tanaka S. 2010. Bacterial microcompartment organelles: protein shell structure and evolution. Annu Rev Biophys 39:185-205.

16. Mayer MJ, Juodeikis R, Brown IR, Frank S, Palmer DJ, Deery E, Beal DM, Xue WF, Warren MJ. 2016. Effect of bio-engineering on size, shape, composition and rigidity of bacterial microcompartments. Sci Rep 6:36899.

17. Hartmann M, Berditsch M, Hawecker J, Ardakani MF, Gerthsen D, Ulrich AS. 2010. Damage of the bacterial cell envelope by antimicrobial peptides gramicidin $S$ and PGLa as revealed by transmission and scanning electron microscopy. Antimicrobial Agents and Chemotherapy 54:3132-3142. 
bioRxiv preprint doi: https://doi.org/10.1101/2020.09.14.297432; this version posted September 17, 2020. The copyright holder for this preprint (which was not certified by peer review) is the author/funder, who has granted bioRxiv a license to display the preprint in perpetuity. It is made available under aCC-BY-ND 4.0 International license.

12.09.2020

Intracellular Salmonella ultrastructural heterogeneity

18. Helander IM, Nurmiaho-Lassila EL, Ahvenainen R, Rhoades J, Roller S. 2001. Chitosan disrupt the barrier properties of the outer membrane of gram-negative bacteria. International Journal of Food Microbiology 71:235-244.

19. López-Heras M, Theodorou IG, Leo BF, Ryan MP, Porter AE. 2015. Towards understanding the antibacterial activity of $\mathrm{Ag}$ nanoparticles: electron microscopy in the analysis of the materials-biology interface in the lung. Environmental Science: Nano 2:312-326.

20. Yossa N, Patel J, Macarisin D, Milner P, Murphy C, Bauchan G, Lo YM. 2014. Antibacterial Activity of Cinnamaldehyde and Sporan against Escherichia coli O157:H7 and Salmonella. Journal of Food Processing and Preservation 38:749-757.

21. Zhang X, Ashby R, Solaiman DKY, Uknalis J, Fan X. 2016. Inactivation of Salmonella spp. and Listeria spp. by palmitic, stearic, and oleic acid sophorolipids and thiamine dilauryl sulfate. Frontiers in Microbiology 7:1-11.

22. Via LE, Deretic D, Ulmer RJ, Hibler NS, Huber LA, Deretic V. 1997. Arrest of mycobacterial phagosome maturation is caused by a block in vesicle fusion between stages controlled by rab5 and rab7. J Biol Chem 272:13326-31.

23. Garai P, Berry L, Moussouni M, Bleves S, Blanc-Potard AB. 2019. Killing from the inside: Intracellular role of T3SS in the fate of Pseudomonas aeruginosa within macrophages revealed by mgtC and oprF mutants. PLoS Pathog 15:e1007812.

24. Cueto JA, Rodriguez C, Vega IA, Castro-Vazquez A. 2015. Immune Defenses of the Invasive Apple Snail Pomacea canaliculata (Caenogastropoda, Ampullariidae): Phagocytic Hemocytes in the Circulation and the Kidney. PLoS One 10:e0123964.

25. Salah IB, Ghigo E, Drancourt M. 2009. Free-living amoebae, a training field for macrophage resistance of mycobacteria. Clin Microbiol Infect 15:894-905.

26. Lamrabet O, Mba Medie F, Drancourt M. 2012. Acanthamoeba polyphaga-enhanced growth of Mycobacterium smegmatis. PLoS One 7:e29833.

27. Lemmer Y, Kalombo L, Pietersen RD, Jones AT, Semete-Makokotlela B, Van Wyngaardt S, Ramalapa B, Stoltz AC, Baker B, Verschoor JA, Swai HS, de Chastellier C. 2015. Mycolic acids, a promising mycobacterial ligand for targeting of nanoencapsulated drugs in tuberculosis. J Control Release 211:94-104.

28. Chan LL, Mak JW, Ambu S, Chong PY. 2018. Identification and ultrastructural characterization of Acanthamoeba bacterial endocytobionts belonging to the Alphaproteobacteria class. PLoS One 13:e0204732.

29. Inglis TJ, Rigby P, Robertson TA, Dutton NS, Henderson M, Chang BJ. 2000. Interaction between Burkholderia pseudomallei and Acanthamoeba species results in coiling phagocytosis, endamebic bacterial survival, and escape. Infect Immun 68:1681-6.

30. Szenasi Z, Endo T, Yagita K, Nagy E. 1998. Isolation, identification and increasing importance of 'free-living' amoebae causing human disease. J Med Microbiol 47:5-16.

31. Paquet VE, Charette SJ. 2016. Amoeba-resisting bacteria found in multilamellar bodies secreted by Dictyostelium discoideum: social amoebae can also package bacteria. FEMS Microbiol Ecol 92.

32. Marciano-Cabral F, Cabral G. 2003. Acanthamoeba spp. as agents of disease in humans. Clin Microbiol Rev 16:273-307.

33. Sedzicki J, Tschon T, Low SH, Willemart K, Goldie KN, Letesson JJ, Stahlberg H, Dehio C. 2018. 3D correlative electron microscopy reveals continuity of Brucellacontaining vacuoles with the endoplasmic reticulum. J Cell Sci 131.

34. Zhang K, Dupont A, Torow N, Gohde F, Leschner S, Lienenklaus S, Weiss S, Brinkmann MM, Kuhnel M, Hensel M, Fulde M, Hornef MW. 2014. Age-dependent enterocyte invasion and microcolony formation by Salmonella. PLoS Pathog 10:e1004385. 
bioRxiv preprint doi: https://doi.org/10.1101/2020.09.14.297432; this version posted September 17, 2020. The copyright holder for this preprint (which was not certified by peer review) is the author/funder, who has granted bioRxiv a license to display the preprint in perpetuity. It is made available under aCC-BY-ND 4.0 International license.

12.09.2020

Intracellular Salmonella ultrastructural heterogeneity

643

644

645

646

647

648

649

650

651

652

653

654

655

656

657

658

659

660

661

662

663

664

665

666

667

668

669

670

671

672

673

674

675

676

677

678

679

680

681

682

683

684

685

686

687

688

689

690

691

692

693

35. Silva TP, Gamalier JP, Melo RCN. 2016. TEM as an Important Tool to Study Aquatic Microorganisms and their Relationships with Ecological Processes, Modern Electron Microscopy in Physical and Life Sciences doi:10.5772/61804.

36. Liss V, Hensel M. 2015. Take the tube: Remodelling of the endosomal system by intracellular Salmonella enterica. Cellular Microbiology 17:639-647.

37. Gao Y, Spahn C, Heilemann M, Kenney LJ. 2018. The Pearling Transition Provides Evidence of Force-Driven Endosomal Tubulation during Salmonella Infection. mBio 9.

38. Goser V, Kommnick C, Liss V, Hensel M. 2019. Self-Labeling Enzyme Tags for Analyses of Translocation of Type III Secretion System Effector Proteins. mBio 10.

39. Malik-Kale P, Jolly CE, Lathrop S, Winfree S, Luterbach C, Steele-Mortimer O. 2011. Salmonella - at home in the host cell. Frontiers in Microbiology 2:1-9.

40. Liss V, Swart AL, Kehl A, Hermanns N, Zhang Y, Chikkaballi D, Böhles N, Deiwick J, Hensel M. 2017. Salmonella enterica Remodels the Host Cell Endosomal System for Efficient Intravacuolar Nutrition. Cell Host \& Microbe 21:390-402.

41. Noster J, Persicke M, Chao TC, Krone L, Heppner B, Hensel M, Hansmeier N. 2019. Impact of ROS-Induced Damage of TCA Cycle Enzymes on Metabolism and Virulence of Salmonella enterica serovar Typhimurium. Front Microbiol 10:762.

42. Kröger C, Colgan A, Srikumar S, Händler K, Sivasankaran SK, Hammarlöf DL, Canals R, Grissom JE, Conway T, Hokamp K, Hinton JCD. 2013. An infectionrelevant transcriptomic compendium for Salmonella enterica serovar Typhimurium. Cell Host and Microbe 14:683-695.

43. Shen S, Fang FC. 2012. Integrated stress responses in Salmonella. Int J Food Microbiol 152:75-81.

44. Neidhardt FC, Bloch PL, Smith DF. 1974. Culture medium for enterobacteria. J Bacteriol 119:736-47.

45. Popp J, Noster J, Busch K, Kehl A, Zur Hellen G, Hensel M. 2015. Role of host cellderived amino acids in nutrition of intracellular Salmonella enterica. Infect Immun 83:4466-75.

46. Boulos L, Prévost M, Barbeau B, Coallier J, Desjardins R. 1999. LIVE/DEAD® BacLight ${ }^{\mathrm{TM}}$ : application of a new rapid staining method for direct enumeration of viable and total bacteria in drinking water. Journal of Microbiological Methods 37:7786.

47. Ezraty B, Gennaris A, Barras F, Collet JF. 2017. Oxidative stress, protein damage and repair in bacteria. Nat Rev Microbiol 15:385-396.

48. Slauch JM. 2011. How does the oxidative burst of macrophages kill bacteria? Still an open question. Mol Microbiol 80:580-3.

49. Kitzler J, Fridovich I. 1986. Effects of salts on the lethality of paraquat. Journal of Bacteriology 167:346-349.

50. Noster J, Chao TC, Sander N, Schulte M, Reuter T, Hansmeier N, Hensel M. 2019. Proteomics of intracellular Salmonella enterica reveals roles of Salmonella pathogenicity island 2 in metabolism and antioxidant defense. PLoS Pathog 15:e1007741.

51. Jennewein J, Matuszak J, Walter S, Felmy B, Gendera K, Schatz V, Nowottny M, Liebsch G, Hensel M, Hardt WD, Gerlach RG, Jantsch J. 2015. Low-oxygen tensions found in Salmonella-infected gut tissue boost Salmonella replication in macrophages by impairing antimicrobial activity and augmenting Salmonella virulence. Cell Microbiol 17:1833-47.

52. Schulte M, Sterzenbach T, Miskiewicz K, Elpers L, Hensel M, Hansmeier N. 2019. A versatile remote control system for functional expression of bacterial virulence genes based on the tetA promoter. Int J Med Microbiol 309:54-65. 
bioRxiv preprint doi: https://doi.org/10.1101/2020.09.14.297432; this version posted September 17, 2020. The copyright holder for this preprint (which was not certified by peer review) is the author/funder, who has granted bioRxiv a license to display the preprint in perpetuity. It is made available under aCC-BY-ND 4.0 International license.

53. Liss V, Hensel M. 2015. Sample Preparation for Correlative Light and Electron Microscopy (CLEM) Analyses in Cellular Microbiology. Bio-Protocol 5.

54. Coohill TP, Sagripanti JL. 2008. Overview of the inactivation by $254 \mathrm{~nm}$ ultraviolet radiation of bacteria with particular relevance to biodefense. Photochemistry and Photobiology 84:1084-1090.

55. Kim JS, Chowdhury N, Yamasaki R, Wood TK. 2018. Viable but non-culturable and persistence describe the same bacterial stress state. Environ Microbiol 20:2038-2048.

56. McGuffee SR, Elcock AH. 2010. Diffusion, crowding \& protein stability in a dynamic molecular model of the bacterial cytoplasm. PLoS Comput Biol 6:e1000694.

57. Vendeville A, Larivière D, Fourmentin E. 2011. An inventory of the bacterial macromolecular components and their spatial organization, vol 35, p 395-414.

58. Konopka MC, Shkel IA, Cayley S, Record MT, Weisshaar JC. 2006. Crowding and confinement effects on protein diffusion in vivo. J Bacteriol 188:6115-23.

59. Mika JT, van den Bogaart G, Veenhoff L, Krasnikov V, Poolman B. 2010. Molecular sieving properties of the cytoplasm of Escherichia coli and consequences of osmotic stress. Mol Microbiol 77:200-7.

60. Penrod JT, Roth JR. 2006. Conserving a volatile metabolite: a role for carboxysomelike organelles in Salmonella enterica. J Bacteriol 188:2865-74.

61. Dalebroux ZD, Edrozo MB, Pfuetzner RA, Ressl S, Kulasekara BR, Blanc MP, Miller SI. 2015. Delivery of cardiolipins to the Salmonella outer membrane is necessary for survival within host tissues and virulence. Cell Host and Microbe 17:441-451.

62. Romantsov T, Guan Z, Wood JM. 2009. Cardiolipin and the osmotic stress responses of bacteria. Biochimica et Biophysica Acta (BBA) - Biomembranes 1788:2092-2100.

63. Seydlová G, Fišer R, Čabala R, Kozlík P, Svobodová J, Pátek M. 2013. Surfactin production enhances the level of cardiolipin in the cytoplasmic membrane of Bacillus subtilis. Biochimica et Biophysica Acta - Biomembranes 1828:2370-2378.

64. Dalebroux ZD, Matamouros S, Whittington D, Bishop RE, Miller SI. 2014. PhoPQ regulates acidic glycerophospholipid content of the Salmonella Typhimurium outer membrane. Proceedings of the National Academy of Sciences 111:1963-1968.

65. Dong H, Zhang Z, Tang X, Huang S, Li H, Peng B, Dong C. 2016. Structural insights into cardiolipin transfer from the inner membrane to the outer membrane by PbgA in Gram-negative bacteria. Scientific Reports 6:1-10.

66. Deatherage BL, Cookson BT. 2012. Membrane vesicle release in bacteria, eukaryotes, and archaea: a conserved yet underappreciated aspect of microbial life. Infect Immun 80:1948-57.

67. Lopez-Amoros R, Castel S, Comas-Riu J, Vives-Rego J. 1997. Assessment of E. coli and Salmonella viability and starvation by confocal laser microscopy and flow cytometry using rhodamine 123, DiBAC4(3), propidium iodide, and CTC. Cytometry 29:298-305. 
bioRxiv preprint doi: https://doi.org/10.1101/2020.09.14.297432; this version posted September 17, 2020. The copyright holder for this preprint (which was not certified by peer review) is the author/funder, who has granted bioRxiv a license to display the preprint in perpetuity. It is made available under aCC-BY-ND 4.0 International license.

12.09.2020

Intracellular Salmonella ultrastructural heterogeneity

734

735

736

737

738

739

740

741

742

743

744

745

746

747

748

749

750

751

752

753

754

755

756

757

758

\section{Figure Legends}

Figure 1: Environmental stress affects STM ultrastructure. A-D) Energy-filtered TEM (EF-TEM) micrographs $(120 \mathrm{keV})$ showing electron-lucent STM WT after growth in PCN medium (A), PCN medium supplemented with AA (B), and electron-lucent (asterisks) and electron-dense (arrowheads) STM WT in LB medium subcultured for $3.5 \mathrm{~h}(\mathbf{C}, \mathbf{D})$. Arrows indicate cells undergoing division. E) Comparison of STM WT densities in LB medium shown as mean \pm SD of different values between bacterial cytoplasm mean grey values (MGV) and background MGV (see Fig. S1A, B, pooled data). F) Comparison of density ratio: electron-dense (arrowheads in $\mathbf{C}, \mathbf{D}, \mathbf{I}, \mathbf{J}$ ) vs. electron-lucent (asterisks in C, D, H) STM WT and $\triangle \operatorname{sod} A B$ cultured in LB medium without or after PQ treatment. Numbers of cells quantified: $30,22,32$, and 33, for STM WT, $\triangle \operatorname{sod} A B 0 \mu \mathrm{M} \mathrm{PQ}, \Delta \operatorname{sod} A B 1 \mu \mathrm{M} \mathrm{PQ}$, and $\triangle \operatorname{sodAB} 5 \mu \mathrm{M}$ PQ, respectively. G-K) TEM micrographs showing STM $\triangle \operatorname{sodAB}$ without $(\mathbf{G}$, $\mathbf{H})$, or after treatment with PQ at $1 \mu \mathrm{M}(\mathbf{I})$, or $5 \mu \mathrm{M}(\mathbf{J}, \mathbf{K})$. L) Comparison of the relative numbers of STM $\triangle \operatorname{sodAB}$ ED. Numbers of cells quantified: 211,157 , and 135 , for $0 \mu \mathrm{M}, 1$ $\mu \mathrm{M}$, and $5 \mu \mathrm{M} \mathrm{PQ}$, respectively. Scale bars, $500 \mathrm{~nm}$. Statistical analysis was accomplished by Student's $t$-test and significance levels are indicated as follows: *, p < 0.05; **, p < 0.01; ***, $\mathrm{p}<0.001 ;$ n.s., not significant.

\section{Figure 2: STM $\triangle \operatorname{sod} A B$ has growth defects and exhibits membrane abnormalities. A, B)}

Growth of STM WT (A) and STM $\triangle \operatorname{sodAB}(\mathbf{B})$ on agar plates. C-H) PI staining of STM $\triangle \operatorname{sod} A B$ cultured for $3.5 \mathrm{~h}$ in $\mathrm{LB}$ medium without treatment $(\mathbf{C})$, after treatment with $1 \mu \mathrm{M}$ PQ (D, E), or $5 \mu \mathrm{M}$ PQ (F, G) prior to TEM. D and $\mathbf{F}$ show bacteria with PI addition at time $0 \mathrm{~h}$ after PQ treatment, while $\mathbf{E}$ and $\mathbf{G}$ show cells with PI addition $12 \mathrm{~h}$ after PQ treatment. $\mathbf{H}$ ) Quantification of PI-positive STM $\triangle \operatorname{sodAB}$ cells. The line in $\mathbf{H}$ represents the level of PIpositive cells in untreated sample (related to Fig. S2). Number or quantified cells: 13,468, 
bioRxiv preprint doi: https://doi org/10.1101/2020.09.14.297432; this version posted September 17, 2020. The copyright holder for this preprint (which was not certified by peer review) is the author/funder, who has granted bioRxiv a license to display the preprint in perpetuity. It is made available under aCC-BY-ND 4.0 International license.

12.09.2020

Intracellular Salmonella ultrastructural heterogeneity

$1,565,6,162$, and 2,133 , for $1 \mu \mathrm{M}$ PQ at $0 \mathrm{~h}, 1 \mu \mathrm{M}$ PQ at $12 \mathrm{~h}, 5 \mu \mathrm{M}$ PQ at $0 \mathrm{~h}$, and $5 \mu \mathrm{M}$ PQ at $12 \mathrm{~h}$, respectively. I) Relative numbers of STM $\triangle \operatorname{sodAB}$ with cell envelope invaginations (arrowheads in $\mathbf{J}-\mathbf{L})$ of untreated control $(\mathbf{J}, \mathbf{M})$, or treated with $1 \mu \mathrm{M}(\mathbf{K})$ or $5 \mu \mathrm{M}$ PQ $(\mathbf{L}, \mathbf{N}$, O). J-O) TEM analysis by $120 \mathrm{keV} \mathrm{EF-TEM} \mathrm{of} \mathrm{STM} \triangle$ sodAB shown in $\mathbf{C}, \mathbf{D}, \mathbf{F}$, fixed at $0 \mathrm{~h}$ post PQ treatment. Numbers of cells quantified: 113,93 , and 98 , for $0 \mu \mathrm{M}, 1 \mu \mathrm{M}$, and $5 \mu \mathrm{M}$ PQ, respectively. N, O) STM $\triangle \operatorname{sod} A B$ treated with $5 \mu \mathrm{M}$ PQ shows membrane ruptures and lysis spot (asterisks). Scale bars, $10 \mu \mathrm{m}(\mathbf{C}-\mathbf{G}), 1 \mu \mathrm{m}$ (J-L), $200 \mathrm{~nm}$ (M-O).

\section{Figure 3: STM WT shows ED cells after PQ treatment in PCN pH 7.4 medium}

supplemented with AA. A, B) TEM micrograph of STM WT cultured in PCN medium, pH 7.4 for $3.5 \mathrm{~h}$ and shifted to fresh PCN medium, $\mathrm{pH} 7.4$ for incubation without (control $\mathbf{A}$ ) or with $1 \mathrm{mM}$ PQ (B). C-F) Electron micrograph of STM WT cultured in PCN medium pH 7.4 (C and D), or pH 5.8 (E and $\mathbf{F})$ supplemented with AA for $3.5 \mathrm{~h}$ and shifted to the same fresh PCN medium for incubation without (control $\mathbf{C}$ and $\mathbf{E}$ ), or with $1 \mathrm{mM}$ PQ (D and F). Scale bars, $1 \mu \mathrm{m}$. G) CFU counts obtained for STM WT without or with addition of $1 \mathrm{mM}$ PQ. STM was subcultured for $3.5 \mathrm{~h}$ in PCN with or without AA supplementation, at $\mathrm{pH} 7.4$ or $\mathrm{pH}$ 5.8.

Figure 4: Ultrastructural diversity of intracellular STM WT. STM WT was subcultured in LB for $3.5 \mathrm{~h}$ and used to infect HeLa cells. Infected cells were fixed $16 \mathrm{~h}$ p.i. and analyzed by EF-TEM (120 keV). Micrographs show electron-dense (A) and electron-lucent STM WT (B, C). Dividing STM WT cells shown in C. Dashed boxes indicate areas enlarged in a. Scale bars, $1 \mu \mathrm{m}$. 
bioRxiv preprint doi: https://doi.org/10.1101/2020.09.14.297432; this version posted September 17, 2020. The copyright holder for this preprint (which was not certified by peer review) is the author/funder, who has granted bioRxiv a license to display the preprint in perpetuity. It is made available under aCC-BY-ND 4.0 International license.

12.09.2020

Intracellular Salmonella ultrastructural heterogeneity

783

784

785

786

787

788

789

790

791

792

793

794

795

796

797

798

799

800

801

802

803

804

805

806

Figure 5: Hyper-replicating intracellular STM WT forms subpopulations of metabolically active and inactive bacteria. STM WT harboring dual-color vitality reporter was visualized inside HeLa LAMP1-GFP cells 8 h and 16 h p.i. Gfp was constitutively expressed in STM WT, while dsred expression was induced by addition of AHT $2 \mathrm{~h}$ prior to imaging. A) DsRed is visible in all intracellular STM WT associated with SIF formation $8 \mathrm{~h}$ p.i. (yellow cells in merge, red arrows). B) At $16 \mathrm{~h}$ p.i., hyper-replicating intracellular STM WT either lack DsRed (inactive cell indicated by green arrows) or are DsRed-positive (active cells indicated by red arrows). Scale bars, 20 and $5 \mu \mathrm{m}$ in overview and detail, respectively.

Figure 6: CLEM reveals ultrastructural and metabolic diversities of hyper-replicating intracellular STM WT in HeLa cells. HeLa cells seeded on gridded cover slip were infected with STM WT harboring the dual-color vitality reporter and visualized $16 \mathrm{~h}$ p.i. Gfp was constitutively expressed in STM WT while dsred expression was induced by AHT $2 \mathrm{~h}$ prior to imaging by confocal FM. Subsequently, cells were processed for TEM. A) Representative HeLa cell with hyper-replicating intracellular STM WT, either DsRed-positive (active cells) or DsRed-negative (inactive). B) Representative HeLa cell with replicating STM WT, which are DsRed-positive. For CLEM, EF-TEM micrographs of $200 \mathrm{~nm}$ thick sections of infected HeLa cells obtained at $120 \mathrm{keV}$ were correlated with GFP or DsRed fluorescence signals of confocal sections after deconvolution. a-d) High-resolution CLEM of ROIs (white boxes) harboring intracellular STM WT of diverse electron density (TEM) and activity levels (DsRed, FM). Note ED and EL STM during division (Ac), which are DsRed-negative. 'Wide' (w) and 'thin' (t) STM are marked. Scale bars, $10 \mu \mathrm{m}$ (A, all overviews and B, LM overviews), $1 \mu \mathrm{m}$ (B, TEM overviews, Aa-Ad and Ba), $500 \mathrm{~nm}(\mathbf{B b}-\mathbf{d})$. 
bioRxiv preprint doi: https://doi.org/10.1101/2020.09.14.297432; this version posted September 17, 2020. The copyright holder for this preprint (which was not certified by peer review) is the author/funder, who has granted bioRxiv a license to display the preprint in perpetuity. It is made available under aCC-BY-ND 4.0 International license.

12.09.2020

Intracellular Salmonella ultrastructural heterogeneity

807

808

809

810

811

812

813

814

815

816

817

818

819

820

821

822

823

824

825

826

827

828

829

830

831

Figure 7: High-resolution CLEM of intracellular STM WT precisely locates proteins in bacterial cytoplasm: halo-like distribution of GFP/DsRed and electron density in single

cells. Intracellular STM WT harboring dual-color vitality reporter was visualized inside HeLa cells seeded on gridded cover slips 16 h p.i. STM WT constitutively expressed $g f p$, while dsred expression was induced by AHT 2 h prior to imaging by confocal FM. Subsequently, cells were processed for TEM. Aa-Ac) Overview of HeLa cell with hyper-replicating intracellular STM WT (GFP, green) showing metabolic activity (DsRed, yellow in merge).

Dashed boxes indicate CLEM region in B and C. B, C) CLEM of consecutive $200 \mathrm{~nm}$ thick sections of region with STM WT of halo-like electron density (indicated by arrowheads). GFP and DsRed confocal fluorescence signals after deconvolution (d-f) are correlated with 120 keV EF-TEM micrographs. GFP and DsRed are distributed in a halo-shaped electron density. Scale bars, $10 \mu \mathrm{m}(\mathbf{A}), 1 \mu \mathrm{m}(\mathbf{B}, \mathbf{C})$.

Figure 8: 'Halo' type of STM WT dominates in critical environmental conditions. A) Comparison of relative numbers of halo-shaped STM WT and $\triangle \operatorname{sodAB}$ cultured in LB medium overnight $(\mathrm{o} / \mathrm{n})$ or further subcultured for $3.5 \mathrm{~h}$ in fresh medium prior to TEM preparation (TEM in Fig. S1D-G). Number of quantified cells: 1,032, 819, 747, and 510, for WT $3.5 \mathrm{~h}$, WT o/n, $\triangle \operatorname{sod} A B 3.5 \mathrm{~h}$, and $\triangle \operatorname{sod} A B \mathrm{o} / \mathrm{n}$, respectively. B, C) STM WT was irradiated $60 \mathrm{sec}$ with UV light (305 nm) prior to TEM preparation. B) Comparison of relative numbers of halo-shaped STM WT after UV irradiation (arrowheads in C) to its control, the same LB culture without UV treatment. Numbers of quantified cells: 716 and 612, for UVtreated and non-treated groups, respectively. C) TEM micrograph of UV-treated STM WT with halo-shaped profiles (indicated by arrowheads). D-I) TEM micrographs of HeLa cells 16 h p.i. with STM WT. Infected HeLa cells containing hyper-replicating STM WT show disrupted cell membranes and signs of cell death. Nearly all intracellular STM WT have 
bioRxiv preprint doi: https://doi.org/10.1101/2020.09.14.297432; this version posted September 17, 2020. The copyright holder for this preprint (which was not certified by peer review) is the author/funder, who has granted bioRxiv a license to display the preprint in perpetuity. It is made available under aCC-BY-ND 4.0 International license.

12.09.2020

Intracellular Salmonella ultrastructural heterogeneity

832 cytoplasmic densities distributed as a halo (arrowheads). Scale bars, $2.5 \mu \mathrm{m}(\mathbf{D}, \mathbf{E}), 1 \mu \mathrm{m}(\mathbf{C}$,

833 F-I).

834 
bioRxiv preprint doi: https://doi org/10.1101/2020.09.14.297432; this version posted September 17, 2020. The copyright holder for this preprint (which was not certified by peer review) is the author/funder, who has granted bioRxiv a license to display the preprint in perpetuity. It is made available under aCC-BY-ND 4.0 International license.

12.09.2020

Intracellular Salmonella ultrastructural heterogeneity

835

836

837

838

839

840

841

842

843

844

845

846

847

848

849

850

851

852

853

854

855

856

857

858

Figure S1 (related to Fig. 1): A-C) Quantification of data obtained by $120 \mathrm{keV}$ EF-TEM imaging (related with Fig. 1C-E). A) Comparison of electron densities (difference values of MGV of STM cytoplasm to MGV of background) of ED and EL STM WT in different regions of sample. Averages of electron densities $(\mathbf{B})$, and $(\mathbf{C})$ averaged density ratio (mean \pm SD). D-M) Electron micrographs at $50 \mathrm{keV}$ of STM WT and $\triangle \operatorname{sodAB}$ strains from o/n cultures or $3.5 \mathrm{~h}$ subcultures in LB medium (D-G), STM WT from o/n or $3.5 \mathrm{~h}$ subcultures in PCN, pH 7.4 with $(\mathbf{J}, \mathbf{K})$, or without AA supplementation $(\mathbf{H}, \mathbf{I})$, or in PCN, pH $5.8(\mathbf{L}, \mathbf{M})$. Arrows indicate cells with mixed electron densities and halo-like distribution in $\mathbf{E}$. Arrowheads in $\mathbf{G}$ indicate cells of STM $\triangle \operatorname{sod} A B$ with translucent spot not found in $3.5 \mathrm{~h}$ subculture of the same culture. Scale bar, $1 \mu \mathrm{m}$. Statistical analysis was accomplished by Student's $t$-test, and significance levels are indicated as follows: $*, \mathrm{p}<0.05 ; * *, \mathrm{p}<0.01$; $* * *, p<0.001 ;$ n.s., not significant.

Figure S2 (related to Fig. 2): PQ treatments affects membrane integrity to similar extend in STM WT and $\triangle \operatorname{sod} A B$ strains. A) Relative numbers of PI-positive STM $\triangle \operatorname{sod} A B$ without and after treatment with PQ. Obvious increase of PI-load events in culture was achieved after treatment with $50 \mu \mathrm{M}$ PQ in comparison to control (no treatment) and treatment with PQ at concentrations of $5 \mu \mathrm{M}$ or $10 \mu \mathrm{M}$. Number of cells quantified: 3,876 , $1,5825,15,804$, and 18,016 , for $0 \mu \mathrm{M}, 5 \mu \mathrm{M}, 10 \mu \mathrm{M}$, and $50 \mu \mathrm{M} \mathrm{PQ}$, respectively. B, C) Comparison of PQ effects at $50 \mu \mathrm{M}$ PQ between STM WT and $\triangle \operatorname{sodAB}$ : the relative number of PI-positive cells and fluorescence intensities of PI. PI was loaded $12 \mathrm{~h}$ after PQ treatment. STM $\triangle \operatorname{sod} A B$ shows high variability in number and degree (intensities) of PI-load events in the culture (controls). Statistical analysis was accomplished by Student's $t$-test and 
bioRxiv preprint doi: https://doi.org/10.1101/2020.09.14.297432; this version posted September 17, 2020. The copyright holder for this preprint (which was not certified by peer review) is the author/funder, who has granted bioRxiv a license to display the preprint in perpetuity. It is made available under aCC-BY-ND 4.0 International license.

12.09.2020

Intracellular Salmonella ultrastructural heterogeneity

859

860

861

862

863

864

865

866

867

868

869

870

871

872

873

874

875

876

877

878

879

880

881

882

883

significance levels are indicated as follows: $*, \mathrm{p}<0.05 ; * *, \mathrm{p}<0.01 ; * * *, \mathrm{p}<0.001 ; \mathrm{n} . \mathrm{s.}$, not significant.

Figure S3 (related to Fig. 3): Treatments of STM WT using various stressors have impact on ultrastructure. A-F) Electron micrograph of STM WT cultured in PCN, pH 7.4 for $3.5 \mathrm{~h}$ and shifted to fresh PCN, $\mathrm{pH} 7.4$ (A-C), or PCN, pH 5.8 (D-F) for incubation without PQ (control A, D), with $100 \mu \mathrm{M}$ PQ (B, D), or $500 \mu \mathrm{M}$ PQ (C, F). G-L) EF-TEM micrographs of STM WT without (control), after $100 \mu \mathrm{M}$ or $500 \mu \mathrm{M}$ PQ treatment, displayed as an electron density scale. Arrowheads point to cells with denser cytoplasm compared to controls. M-O) Electron micrograph of STM WT cultured in PCN, pH 7.4 supplemented with AA for $3.5 \mathrm{~h}$ and shifted to fresh PCN, pH 7.4 for incubation without (control G), with 100 $\mu \mathrm{M}$ PQ (H), or $500 \mu \mathrm{M}$ PQ (I). P-S) Electron micrograph of STM WT cultured in PCN, pH 7.4 or PCN, pH 5.8 supplemented with AA for $3.5 \mathrm{~h}$ and shifted to fresh PCN, pH 3.0 for incubation without (P and R), or with $1 \mathrm{mM}$ PQ (Q and $\mathbf{S})$. T-V) Electron micrographs of STM WT cultured in PCN, pH 7.4 for $3.5 \mathrm{~h}$ and shifted to fresh PCN, pH 7.4 for incubation at $80{ }^{\circ} \mathrm{C}(\mathbf{T})$, to $\mathrm{PCN}, \mathrm{pH} 7.4$ containing $600 \mathrm{mM} \mathrm{NaCl}(\mathbf{U})$, or to pure $\mathrm{H}_{2} \mathrm{O}_{\mathrm{dd}}(\mathbf{V})$. W) Aliquots of STM subcultured for $3.5 \mathrm{~h}$ in PCN, pH 7.4 or PCN, pH 5.8 without PQ treatment, or treatment with $100 \mu \mathrm{M}, 500 \mu \mathrm{M}$ or $1 \mathrm{mM}$ PQ were plated onto agar plates, and CFU were determined. CFU per ml culture are expressed as percentage of CFU of untreated culture. $\mathbf{X}$, Y) Relative numbers of STM WT with shrinkage (arrowhead in D) or features of lysis (arrowhead in $\mathbf{F}$ ) in indicated culture conditions. Features of untreated control samples in \% of total are shown in $\mathbf{X}$ and $\mathbf{x}$-fold increase of features of stressor-treated samples compared to the respective untreated sample is shown in $\mathbf{Y}$. In addition, values of shrinkage and lysis of stress-treated samples in $\%$ of the total population is indicated above. Quantified cells for each condition: 100-300 cells. Scale bars, $1 \mu \mathrm{m}(\mathbf{A}-\mathbf{V}), 250 \mathrm{~nm}$ (detail in C-F). 
bioRxiv preprint doi: https://doi.org/10.1101/2020.09.14.297432; this version posted September 17, 2020. The copyright holder for this preprint (which was not certified by peer review) is the author/funder, who has granted bioRxiv a license to display the preprint in perpetuity. It is made available under aCC-BY-ND 4.0 International license.

12.09.2020

Intracellular Salmonella ultrastructural heterogeneity bacteria, or when protein biosynthesis is experimentally blocked by chloramphenicol $(\mathrm{Cm})$

890 after induction. B) Cytometric gating shows detection of bacteria-sized particles selected by FSC/SSC. GFP-positive cells were gated, the DsRed fluorescence intensity of the GFPpositive bacterial population was determined, and the x-median RFI of the entire population positive counts achieve a maximum already $1 \mathrm{~h}$ after addition of AHT. Cm inhibits synthesis of DsRed after AHT induction. The x-median represents the AHT-induced DsRed signal of the GFP-positive bacterial population. D) DsRed intensity peaks at $0 \mathrm{~h}$ (black), $3 \mathrm{~h}$ (red, start biosynthesis is blocked by addition of Cm (lower histograms), DsRed intensity remains low. successfully blocks DsRed synthesis. Scale bar, $5 \mu \mathrm{m}$. cover slip prior to infection with STM WT harboring the dual-color vitality reporter. Gfp was constitutively expressed in STM WT, while dsred expression was induced by addition of 
bioRxiv preprint doi: https://doi.org/10.1101/2020.09.14.297432; this version posted September 17, 2020. The copyright holder for this preprint (which was not certified by peer review) is the author/funder, who has granted bioRxiv a license to display the preprint in perpetuity. It is made available under aCC-BY-ND 4.0 International license.

12.09.2020

Intracellular Salmonella ultrastructural heterogeneity

AHT $2 \mathrm{~h}$ prior to imaging of selected ROIs by CLSM at 16 p.i. Subsequently, samples were fixed and prepared for TEM by flat-embedding in plastic resin. Coordinates from CLSM were well visible, allowing relocation of ROIs. Resin fragments containing ROIs were dissected and individually fixed to resin blocks for serial $200 \mathrm{~nm}$ ultra-sectioning. After relocation of HeLa cells containing STM WT in TEM modality, serial sections were acquired at $120 \mathrm{keV}$ with energy filtering ( $\Omega$ filter). This approach significantly reduced time needed for sample preparation to image whole cells with TEM, providing the opportunity to collect data of high quality at optimal resolutions for correlation or TEM analysis. B) CLEM imaging steps: visualization by CLSM of intracellular STM WT by virtue of GFP fluorescence, and evaluation of metabolic activity by virtue of DsRed intensity (Z-stack through STM population, maximum intensity projection is shown), registration of positions of infected HeLa cells using BF-LM, relocalization of HeLa cells in resin using imprinted CLEM coordinates, TEM imaging, correlation of single CLSM planes with corresponding single TEM images. C) Comparison of fluorescence signals without and with deconvolution using Huygens software. After deconvolution, location of proteins GFP and DsRed was increased, and signal-to-noise ratio was improved. Scale bars, $20 \mu \mathrm{m}$ (B, left panel), $5 \mu \mathrm{m}$ (B, right panel and $\mathbf{C}), 2 \mu \mathrm{m}(\mathbf{C}$, detail).

\section{Figure S6 (related with Fig. 8): UV treatment of STM WT boosts ultrastructural} diversity. A, B) Cultures of STM WT grown o/n in LB were irradiated $60 \mathrm{sec}$. with UV light (305 nm) prior preparation for TEM. As control, STM WT of the same culture was left without irradiation and processed in parallel for TEM. Various ultrastructural profiles were defined: (I) EL, (II) ED, (III) initiated cell death, indicated by shrinkage and damage of inner membrane, or (IV) presence of electron-dense (condensation) and translucent (lysis) spots in the bacterial cytosol, (V) dead cells with condense cytosolic materials and severally 
bioRxiv preprint doi: https://doi org/10.1101/2020.09.14.297432; this version posted September 17, 2020. The copyright holder for this preprint (which was not certified by peer review) is the author/funder, who has granted bioRxiv a license to display the preprint in perpetuity. It is made available under aCC-BY-ND 4.0 International license.

12.09.2020

Intracellular Salmonella ultrastructural heterogeneity

934 fragmented or lacking inner membranes, and (VI) the halo-shaped profile with electron

935 densities at peripheries of cytoplasm. $\mathbf{C}$ ) Comparison of relative numbers of profiles $\mathbf{I}$ to $\mathbf{V}$ of

936 UV-irradiated and untreated STM WT. VI-type relative number is shown in Fig. 8B. Number

937 of quantified cells: 716 and 612 for UV-irradiated and non-treated groups, respectively. D)

938 Comparison of accumulated frequency of STM with I and II profiles (ED+EL), to

939 accumulated frequency of STM with morphological impairments (III-V, shrinkage and lysis

940 of various severity). E) Effect of UV irradiation on bacterial survival. Plating of aliquots of

941 STM cultures onto agar plates and CFU determination was performed for all experiments

942 involving UV irradiation. F) Flow cytometry analysis of STM WT activity using dual-color

943 vitality reporter after UV irradiation. Overnight cultures of STM WT were UV-treated or

944 untreated (control) prior to subculture in fresh LB medium. Induction of $d s r e d$ expression was

945 initiated by addition of AHT at start of subculture. Cultures were sampled in hourly intervals

946 with parallel plating onto agar plates for CFU counts. The x-median RFI represents the

947 AHT-induced DsRed signal of the GFP-positive bacterial population. G) Viability of STM

948 analyzed in $\mathbf{F}$. The amount of living bacteria was calculated and normalized to $100 \%$ of living

949 STM in an untreated sample. As control, STM without UV irradiation were used. Note an

950 increase of DsRed intensity of UV-irradiated bacteria (F) in LB medium although their

951 growth on LB plates is totally inhibited $(\mathbf{G})$. Scale bars, $5 \mu \mathrm{m}(\mathbf{A}, \mathbf{B}), 500 \mathrm{~nm}(\mathbf{I}-\mathbf{V I})$. 


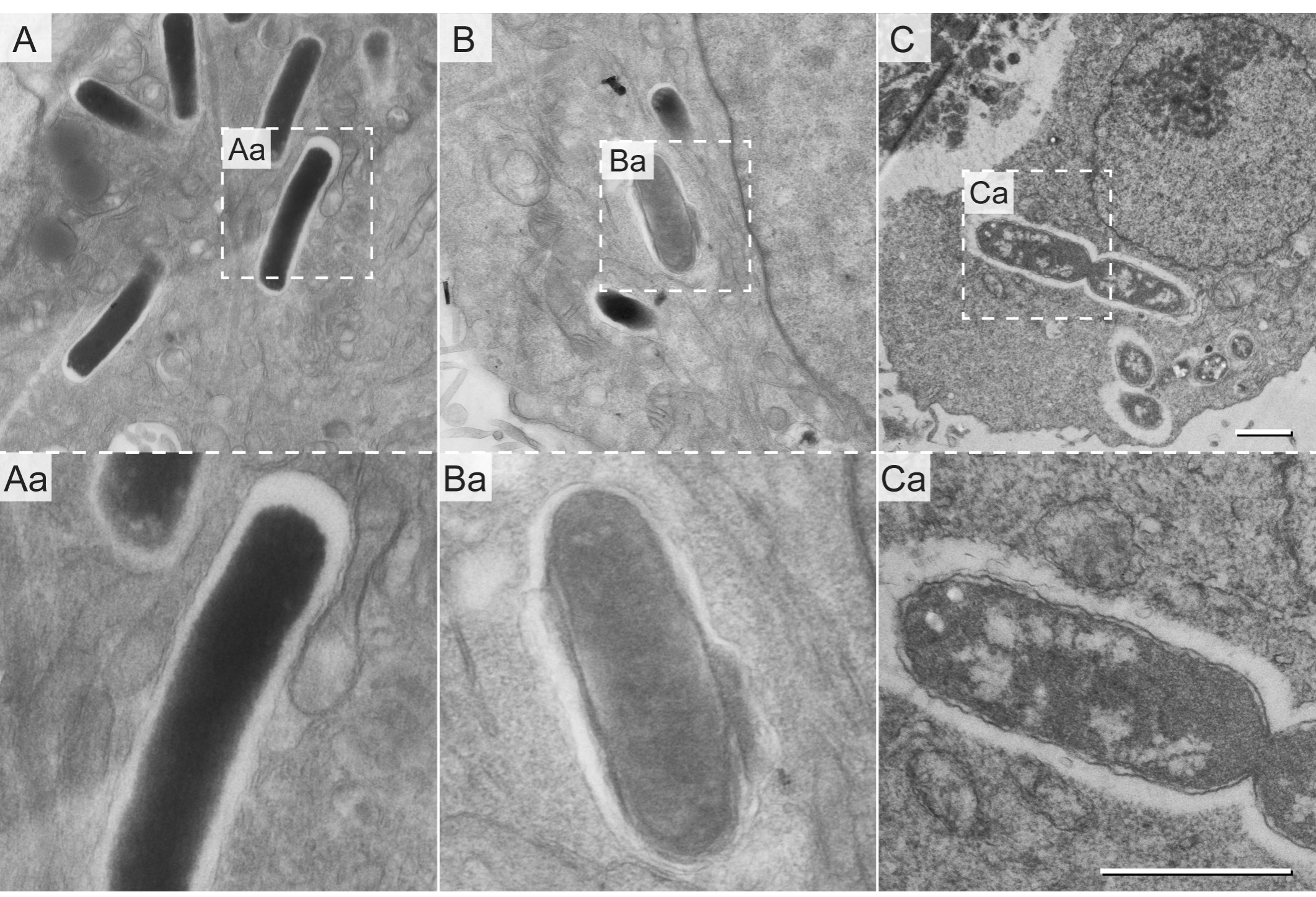


8 h p.i.

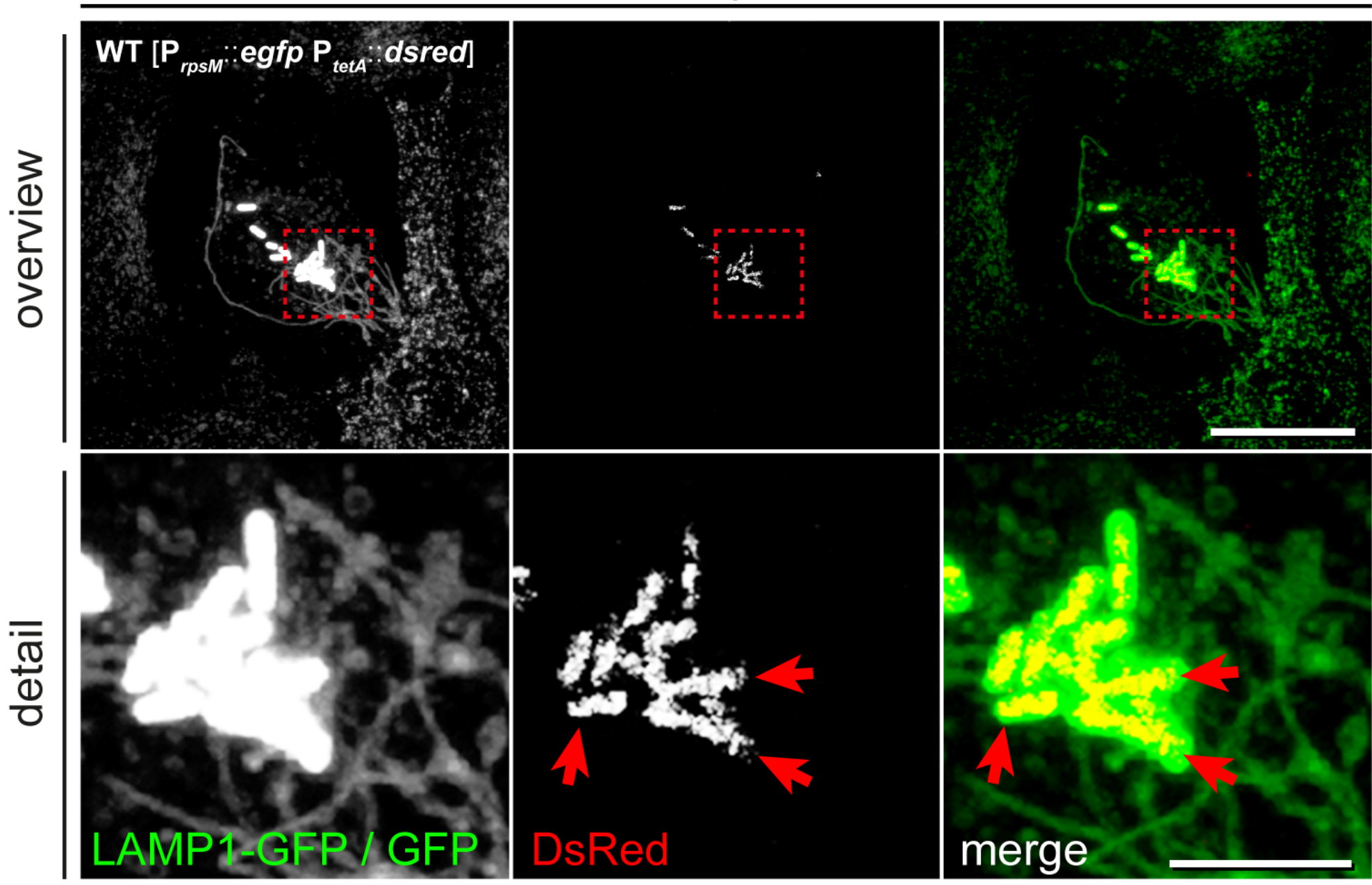

B

16 h p.i.

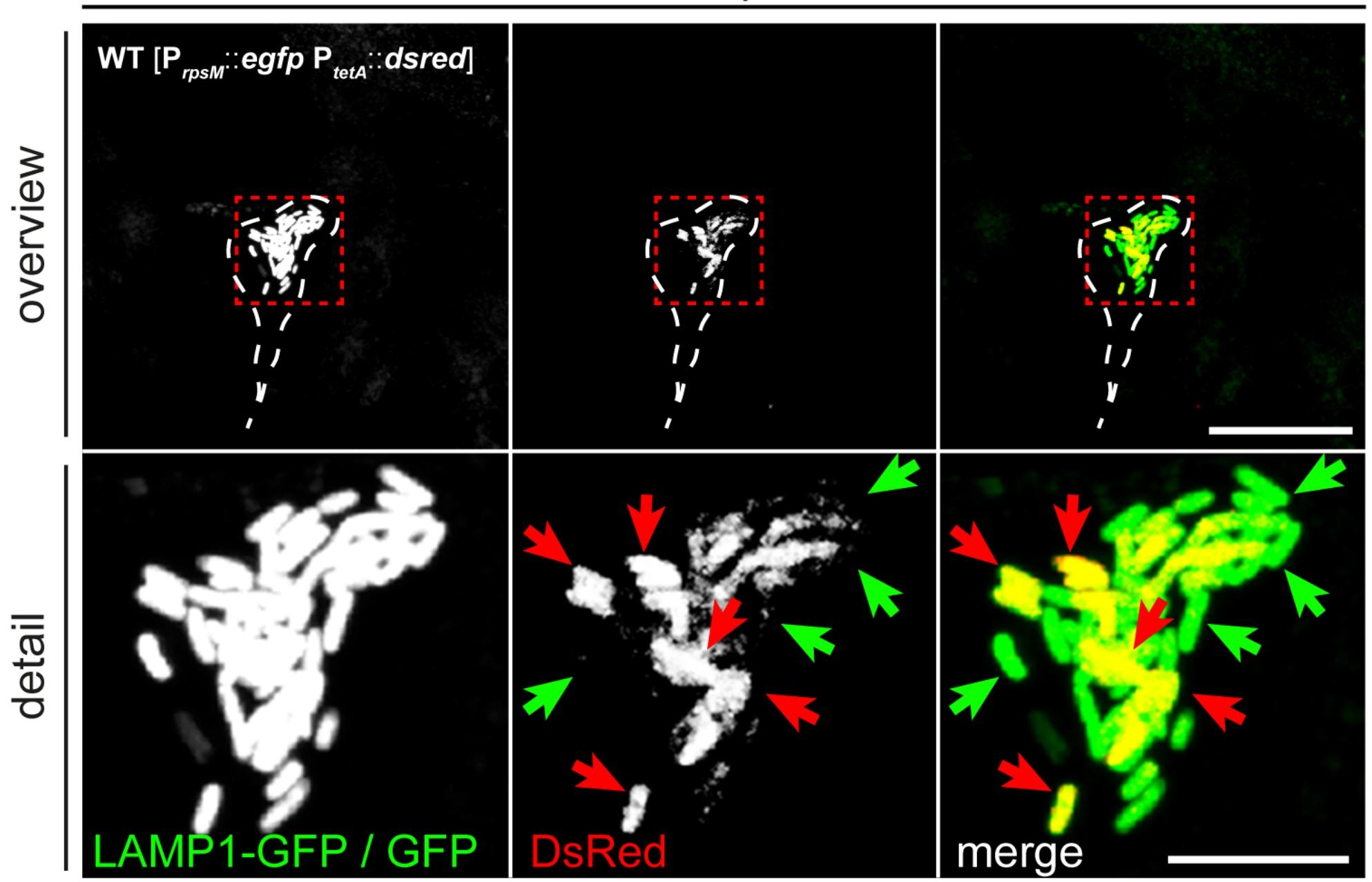


A

LM projection TEM section $(200 \mathrm{~nm})$ B

\section{B} LM projection TEM section (200 nm)

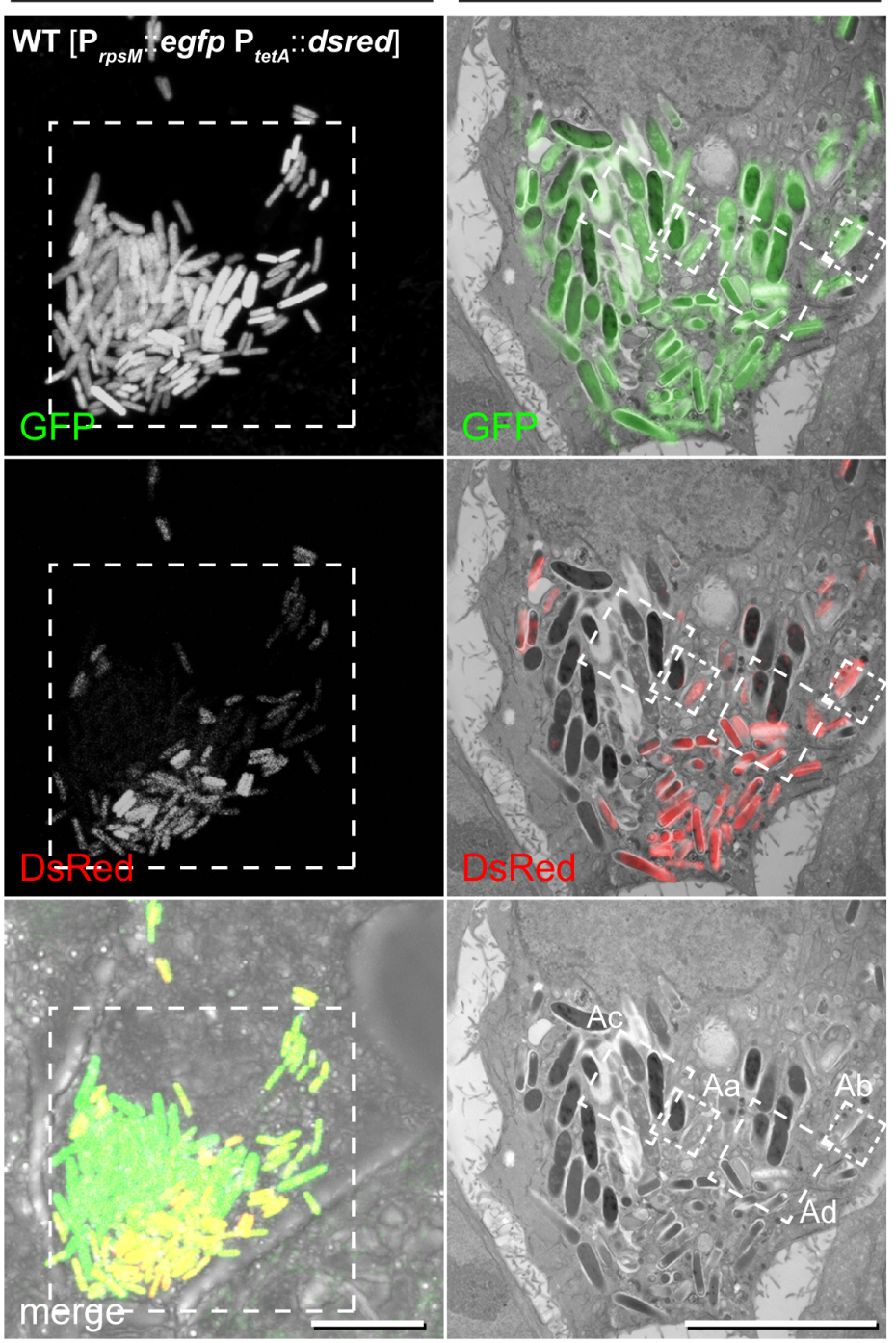

WT $\left[\mathbf{P}_{r p s M}:: \operatorname{egffp} P_{\text {tetA }}:: d s r e d\right]$
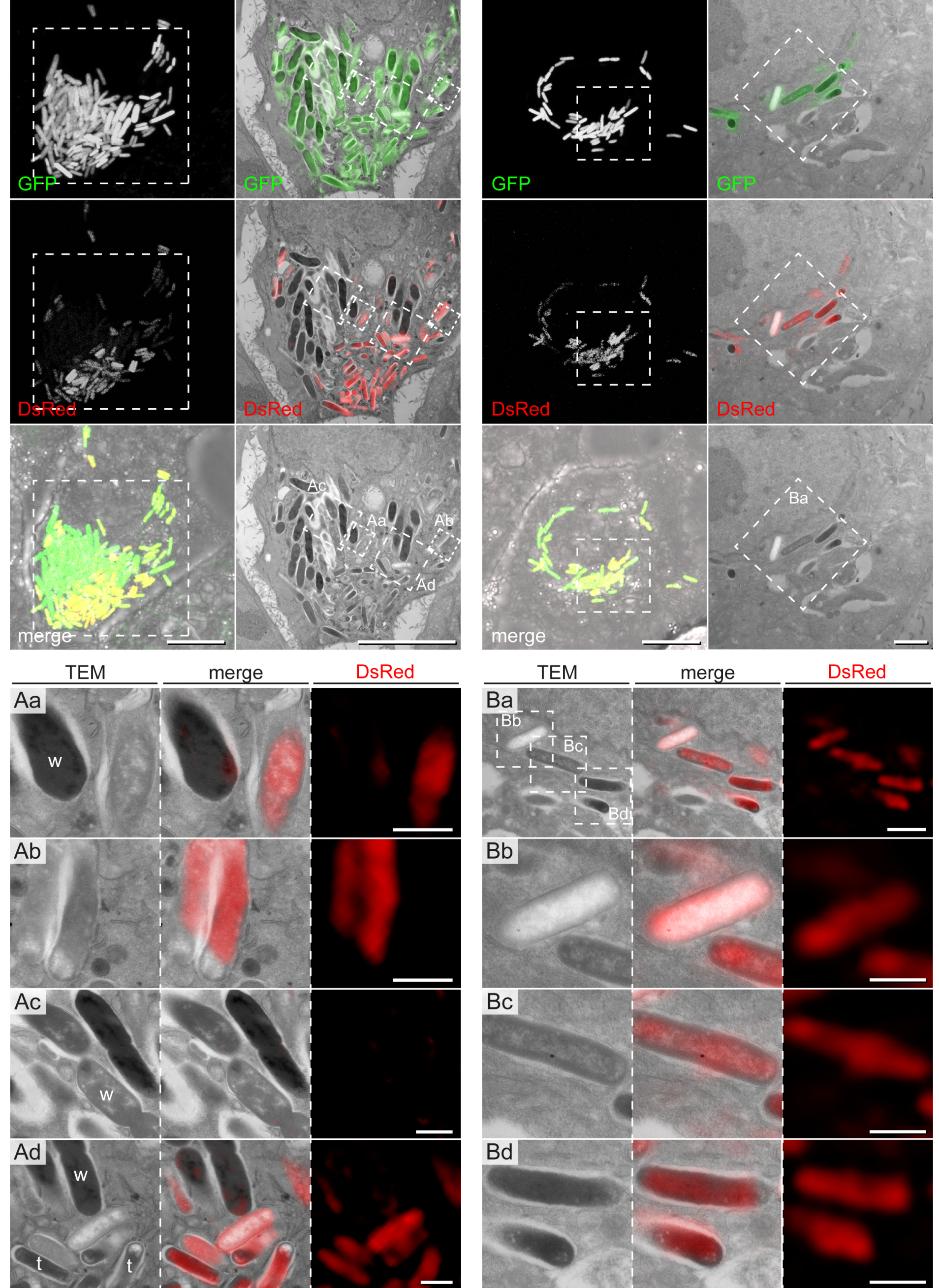

DsRed

\section{$\mathrm{Bb}$}

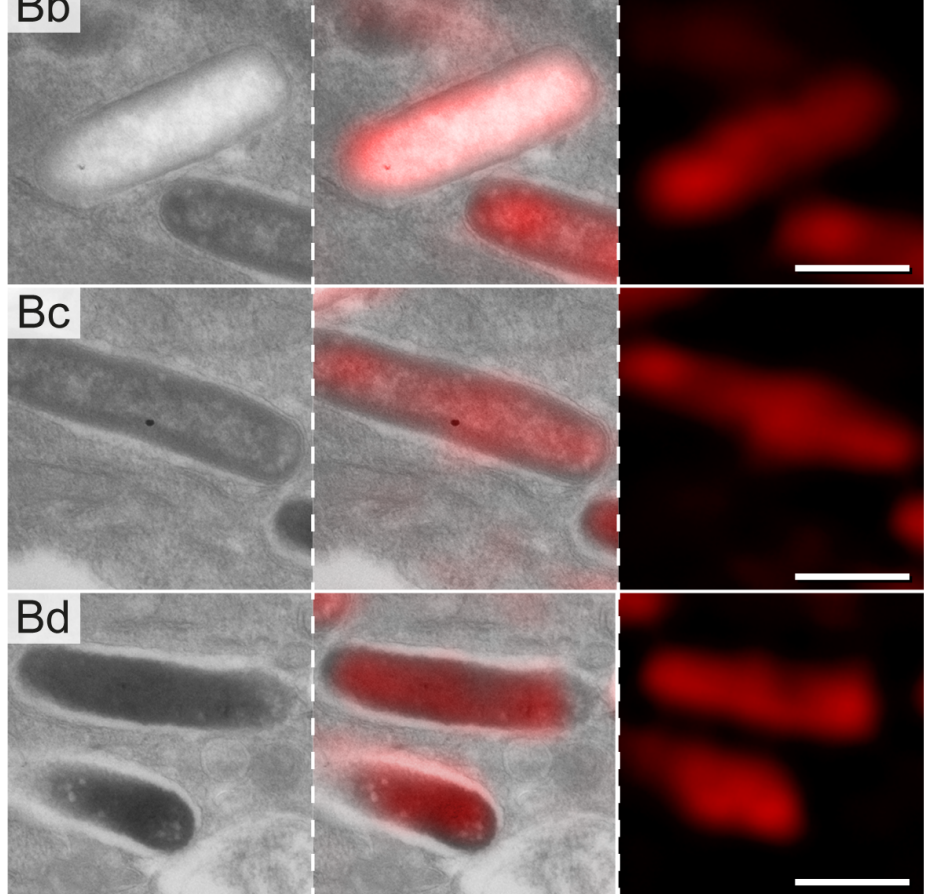


